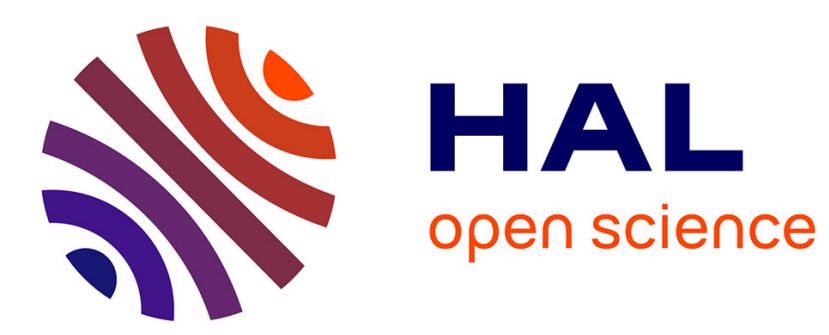

\title{
Accounting for strong sustainability: an intervention-research based approach
}

Souad Taibi, Nicolas Antheaume, Delphine Gibassier

\section{To cite this version:}

Souad Taibi, Nicolas Antheaume, Delphine Gibassier. Accounting for strong sustainability: an intervention-research based approach. Sustainability Accounting, Management and Policy Journal, 2020, 11 (7), pp.1213-1243. 10.1108/SAMPJ-09-2017-0105 . hal-02994017

\section{HAL Id: hal-02994017 https://hal.science/hal-02994017}

Submitted on 7 Nov 2020

HAL is a multi-disciplinary open access archive for the deposit and dissemination of scientific research documents, whether they are published or not. The documents may come from teaching and research institutions in France or abroad, or from public or private research centers.
L'archive ouverte pluridisciplinaire HAL, est destinée au dépôt et à la diffusion de documents scientifiques de niveau recherche, publiés ou non, émanant des établissements d'enseignement et de recherche français ou étrangers, des laboratoires publics ou privés. 
Accounting for sustainable development:

an intervention-research approach

\author{
Souad Taibi \\ IAE Nantes - Économie \& Management \\ Chemin la Censive du Tertre \\ BP 52231
}

44322 Nantes Cedex 3, France

Email: souad_taibi@hotmail.com

Nicolas Antheaume

IAE Nantes - Économie \& Management

Chemin la Censive du Tertre

BP 52231

44322 Nantes Cedex 3, France

Email: Nicolas.Antheaume@univ-nantes.fr

Delphine Gibassier

Audencia Business School

8 Route de la Jonelière, 44312 Nantes, France

Email: dgibassier@audencia.com

Accepted version at Sustainability, Accounting, Management \& Policy Journal

December 2019 


\begin{abstract}
Purpose - The purposes of this paper are first, to empirically illustrate the construction of an accounting for sustainable development tool (Bebbington and Gray, 2001) and, secondly, to discuss the operationalization of accounting for sustainable development (Bebbington and Larrinaga, 2014).
\end{abstract}

Design/methodology/approach - This research is based on a unique interventionresearch approach, the main author having worked part-time for four years on the development of the tool for a business organization in the organic food sector.

Findings - This paper proposes an operationalization of sustainable development within an accounting tool and presents the results of the calculations. It also touches briefly upon the organization's decision not to adopt the tool. The research concludes on the difficulty of operationalizing the economic, social and environmental capitals, while proposing results that demonstrate "unsustainability".

Practical implications - This research in operationalizing sustainable development paves the way for a future potential use of the tool described, and future developments to address the model's current shortcomings, notably in interconnecting social and economic capitals with natural capital.

Social implications - The non-adoption of the accounting tool raises questions about the acceptability among practitioners of visualizing the unsustainability of their own organization, in particular within "green" and "socially responsible" businesses. Moreover, it raises the question of growth, and decoupling of the organization's impact from its economic growth.

Originality/value - This paper makes three contributions to the current literature. First it furthers the discussion on how to operationalize accounting for sustainable development, notably by trying to implement capital as a liability (a debt), placing its "maintenance" at the very heart of the design. Second, it offers an initial operationalization of "system thinking" within a tool to account for sustainable development. Last, it contributes to the literature on "engagement research" through a 4year intervention-research project.

Keywords: accounting for sustainable development, intervention research, capital maintenance, systemic approach, sustainability principles

Paper type: Research paper 


\section{Introduction}

It has been clear for some time that "the baggage associated with conventional accounting is no longer apposite when seeking to account for sustainability" (Gray 2010, p. 47). However, despite attempts at full cost accounting (CICA, 1997; Bebbington et al., 2001; Antheaume, 2004; Herbohn, 2005), sustainable cost (Bebbington and Gray, 2001) and the recent development of multi-capital accounts (Hendriksen et al., 2016), "the difficulty of translating sustainable development to an organizational level is left unaddressed" (Bebbington and Larrinaga, 2014, p. 397). While it is necessary to develop experimentations of new models to bridge that gap, "researchers who have offered their hostages to fortune by way of concrete proposals for actual new forms of accounting remain few in number" (Gray, 1992, p. 400). Following in the steps of researchers such as Jan Bebbington, Kathrin Herbohn, Geoff Lamberton and, more recently, Alexandre Rambaud and Jacques Richard, the main author has endeavored to develop through intervention research a new accounting model that could translate and operationalize sustainable development into accounting. While this paper presents the model and its position in the accounting for sustainable development literature, it must be recognized that "it is (...) difficult to translate radical insight into suggestions for action" (Gray, 1992, p. 400). Indeed, sustainability is a "unique and ongoing experiment", which requires the engagement of researchers (and other participants) in the design of what Correa and Larrinaga (2015, p. 7) call "interim solutions". Therefore, this paper is an account of four years of "struggling with the issue of how, and indeed whether, an account of sustainable development (SD) could be constructed for a single business entity" (Bebbington and Gray, 2001, p. 557). The research documents how the main author developed a tool to examine how to practically link accounting and sustainability (Bebbington and Gray, 2001), which consequently aimed to shift attitudes and practices (Gray, 1992).

The literature has accounted for several attempts at accounting for sustainable development, including, for example, the Sustainability Accounting Model (SAM) (Bebbington et al., 2007). However, Fraser (2012) commented on the SAM that while "the use of the SAM facilitates more sustainable activities and influences organizational decision making", "details of assemblages that disturb the status quo and enable this change remain unclear" (Fraser, 2012, p. 509). We have thus attempted to develop a new sustainability accounting tool to evaluate whether, and how, this tool could generate change. By doing so, we answer Bebbington and Larrinaga's (2014, p. 396) call to pursue endeavors in the area of accounting for sustainable development as it is "yet to fully emerge and its realization requires a re-connection with wider discussions about sustainable development".

This research is based on an attempt to influence managers to incorporate sustainable development into their daily practices by enabling them to evaluate their actions via a balanced rendering of the organization's effect on environmental, societal and financial aspects. The sustainability accounting tool was designed to question business as usual in three ways: first, by correcting the salience of economic data through the presentation of societal and natural capital data in the same formalism and at the same level as the financial data. Secondly by highlighting the notion of debt contracted by the organisation towards natural capital and arising from its very operation. Last of all, by stressing the importance of choosing and collaborating with suppliers to become less unsustainable. 
The paper reports an experiment involving the creation of an accounting tool designed to help companies measure to what extent they are working towards sustainable development. Therefore, the research question is as follows: how can an accounting tool operationalize sustainable development?

The research design is a four-year intervention research project within a medium-sized company in the organic food sector. The organization allowed one of its employees-the main author-to attempt the experimental construction of a sustainability accounting tool. This experiment is therefore based on a detailed case study which documents how the principles of sustainable development were operationalized within a new accounting tool, with the authorization and cooperation of the organization's managers.

While the tool was designed to operationalize sustainable development and influence behavior so as to better integrate sustainability in day-to-day practices, the case reveals that it is difficult to accept results demonstrating "unsustainability", especially in an organization that has developed a number of sustainable practices (including being in the organic food sector). Moreover, several difficulties within the design and operationalization of sustainable development emerged. Therefore, like Bebbington and Gray in 2001, this paper is "an attempt to engage with, reflect upon and re-direct praxis. It suffers all the problems of attempting to apply theory as well as offering a learning experience about mis-specified experiments." (Bebbington and Gray, 2001, p. 558).

This research makes several contributions to the literature. First, it makes several key choices in the operationalization of sustainable development that are new in comparison to past experiments. Notably, the model attempts to operationalize a systemic approach, the concept of resilience and the concept of "thresholds". Second, it is based on a capital approach that regards capital as a liability and emphasizes the concept of "maintenance" (Gray, 1992, p. 416-417). Third, we continue to explore the trade-offs that need to be made when choosing to account for sustainable development, notably when using analogy with financial accounts. Finally, we continue to explore how engagement research can be operationalized through intervention research, and how this method is particularly helpful when exploring new accounts for sustainability (Adams and Larrinaga, 2019).

The remainder of the paper is organized into the following sections. Section 2 discusses the literature on accounting for sustainable development. Section 3 presents the research design used in this paper. Section 4 presents the sustainability accounting model design, and its experimental implementation. Section 5 discusses the findings and is followed by a conclusion.

\section{Literature review}

\subsection{Accounting for sustainable development}

In contrast to traditional social and environmental accounting literature, accounting for sustainable development "places the consideration of the organization of economic life at the center of the debate and calls for a fundamental rethink of how society organizes and conducts itself" (Bebbington, 2001, p. 144). Therefore, Gray and Bebbington (1993, p. 8) stated that "a sustainable organization is one which leaves the biosphere at the end of the accounting period no worse off than it was at the beginning of the accounting period". 
Accounting for sustainable development sees economic, environmental and social issues as interrelated. Gray and Milne (2004) argue that "sustainability is a system-not an organizational-concept". There is a need to think of accounting for sustainable development as a "system", and also to think of each pillar as a system in itself (for example, to think of the environment in a systemic manner). This means that the focus of maintenance will not be on individual parts of nature (water, biodiversity, soil) but on the ecosystem's stability and resilience (Noel and O'Connor, 1998). Folke et al. (2010, p. 3) define resilience as the capacity to "change in order to maintain the same identity, that is its capacity to absorb disturbance and reorganize while undergoing change so as to still retain essentially the same function, structure and feedbacks". In this approach, what is to be maintained, i.e. the capital, is the identity of the ecosystem itself. One could for example consider a centuries-old oak forest as a carbon sink, recreational area and wood source. These services can be rendered by a pine forest as well, and one could consider it sustainable to exploit the oak forest as long as pines are planted at a rate that enables the maintenance of the functions listed above. However, from an ecosystems viewpoint, planting pine trees is not and can no longer be considered a sustainable option, since the tree species has an impact on the soil, which itself impacts the biotope and modifies the ecosystem's identity.

Accounting for sustainable development also means considering that an organization is nested within systems: "interacting with the ecosystems are the human, social, technical and economic systems" (Gray, 1992, p. 406). This means that new accounting models need to take into consideration an economic entity's interactions with a wider environment, for example such as life cycle assessment can (when accounting for broader impacts than the legal boundaries of an entity).

Another consequence of acknowledging interdependence is that the word "capital" (often used in accounting) could be substituted by the word "burden", acknowledging this ecosystem dependence (Birkin, 1996). This notion of "burden" then raises the question of the need for a "base", whose functional abilities would be measured as carrying capacity (Birkin, 1996), because "sustainable outcomes require the rationing of scarce ecosystem capacities" (Milne, 1996, p. 154). To be able to maintain Earth's carrying capacity, accounting for sustainable development needs to work within thresholds ${ }^{1}$, which have recently been embedded within frameworks such as science-based targets, "Future-Fit" and doughnut economics (Raworth, 2017).

Furthermore, accounting for sustainable development is oriented towards "seeking to understand what kind of development should be sought by society and outlining the most appropriate mechanism to do this" (Bebbington, 2001, p. 145).

Bebbington (2001) concludes by reviewing existing tools that may fit the strong sustainability paradigm: sustainable cost calculation (Bebbington and Gray, 2001), full

\footnotetext{
${ }^{1}$ See the work developed by R3.0 (https://reporting3.org/gtac/) on this matter and the summary of current knowledge in the blog "What Are Thresholds \& Allocations, and Why Are They Necessary for Sustainable System Value Creation?" written by Bill Baue and Ralph Thurm, April 2019 and available at https://blog.p2pfoundation.net/what-are-thresholds-allocations-and-why-are-they-necessary-forsustainable-system-value-creation/2019/04/12. Future Fit is available at https://futurefitbusiness.org/ and Science Based Targets is available at https://sciencebasedtargets.org/
} 
cost accounting (Bebbington et al., 2001), advanced sustainability reporting-including life cycle assessment and "écobilans"-full social reporting, social audits, and transparency on transfer pricing. We will now review the experiments of accounting for sustainable development that have been documented in the last 20 years, and their limits.

\subsection{Accounting for sustainable development: tools and experiments}

We will review the attempt at "sustainability costing", the full cost accounting experiments, the City Farm experiment, the Sustainability Assessment Model and finally, the more recent multi-capital accounting models and the French TDL-CARE model. We acknowledge the recent trend in the literature advocating a move away from organization-centered accounting (Russell et al., 2017; Bebbington and Unerman, 2018; Feger and Mermet, 2017), which is affiliated with accounting for sustainable development. However, we do not review them because in our case study, the experiment set up aimed to develop accounting for an organization, albeit with strong sustainability principles and sustainable development at the center of the experimentation (Bebbington, 2001).

\subsubsection{Sustainability cost}

The sustainability cost experiment is based on the idea that maintaining capital could be used "as heuristics in order to understand SD in the context of business" (Bebbington and Gray, 2001, p. 562). As "a level of sustainable activity is that level which maintains the planet's capital” (Gray, 1992, p. 417), a sustainable organization must therefore keep its capital intact. Consequently, Bebbington and Gray (2001) saw the tracking of capital flows as a possible means to account for advancing towards or retreating from sustainability. This experiment was to find out what the additional costs would be, i.e. those that "must be borne by the organization if the organizational activity were not to leave the planet worse off, i.e. what it would cost at the end of the accounting period to return the planet and biosphere to the point it was at the beginning of the accounting period" (Gray, 1992, p. 419). This experiment uses both physical accounts to make calculations before and after remediation has taken place, and traditional financial accounting "to ascertain the notional costs of restoring the environment to its previous state on a year-by-year basis" (Bebbington and Gray, 2001, p. 563).

There were several difficulties in calculating sustainability costs. First, there were expectations that those costs would be enormous. Therefore, Bebbington and Gray decided to build in incrementally what "more sustainable" operations might cost. However, because of the limitations of available possibilities to move their case study organization towards sustainability (in the late '90s), they concluded that their experiment was more an account of unsustainability, which did not question business as usual and did not develop a vision of how an organization could become more sustainable (Bebbington and Gray, 2001).

\subsubsection{Full cost accounting}


In the late '70s, the belief that a less unsustainable economy could be achieved by internalizing "externalities"2 led to the concept of full cost accounting (FCA): "FCA is a means by which market prices can be "corrected" in order to create an economic system that is more likely to deliver "sustainable development"” (Bebbington et al., 2001, p. 5). According to Bebbington and Larrinaga, full cost accounting is one of the most promising accounting tools for sustainable development as it moves "beyond the entity to identify externalities" (Bebbington and Larrinaga, 2014, p. 396). Moreover, Unerman et al. (2018) insist that full cost accounting could help "break down these silos by making explicit the connections between financial and non-financial impacts" (p. 498).

While Unerman et al. (2018) identified a first phase of accounting for externalities in the '70s, we only review full cost accounting experiments published from the "second phase", that is starting with BSO/Origin. The ecological accounts are presented as the net value added of the company, less value lost. The value lost is the environmental costs of externalities, less the environmental costs borne by the company, that mitigate this impact. Huizing and Dekker (1992) emit several criticisms about the BSO/Origin attempt at full cost. First, the "cherry picking" of externalities to be included in their report leads to a less than fully comprehensive picture of their impact. Second, they believed that these accounts would have added value only if considered within an ecosystem of companies (production chain), so potential negative externalities avoided by the company are not just "transferred outside". Their final criticism relates to the use of financialization, through avoidance costs, which is arbitrary and leads to a blind alley.

A second case study was developed by the US Environmental Protection Agency (EPA) on Ontario Hydro's data in 1996. While this project is described in detail within the case study, and recommendations are made for implementation by the US EPA, there are no critical viewpoints in that document about the model or its implementation.

In 1997, the CICA issued a report reviewing the experiments at Ontario Hydro, Landcare Research, and put forward recommendations on the future of full cost accounting, including on the role of accountants and the credibility of the practice. Finally, in 2001, Bebbington et al. codified best practice, dividing full cost accounting into four steps: identifying the cost objective then the boundaries of the entity, third, quantifying physical flows (using eco-balances or Life Cycle Assessment (LCA) or ecological footprints) and last, monetizing impacts.

More recent experimentations of full cost accounting include the one reported by Herbohn (2005). The author mainly reports on the reactions of managers and the potential use of full cost accounting within the case study organization. While managers did see merit in the potential demonstration of a financialized environmental profit, they also "argued that any attempt to measure environmental externalities must be incomplete, and the information should only be a sub-set of reported information" (Herbohn, 2005, p. 527). More recently, a major French company named Kering

\footnotetext{
2 Externalities are comprised of "social, environmental and broader economic impacts arising from the activities of an entity that are borne by others and do not feedback directly into short-term financial consequences for the entity" (Unerman et al., 2018, p. 498).
} 
redeveloped full cost accounting into a large multi-year experiment of a tool they named "E P\&L" (for Environment Profit \& Loss) ${ }^{3}$.

There are two major criticisms of full cost accounting as a potential tool with which to achieve sustainable development. First, monetization can be imprecise and incomplete in representing environmental impacts. Antheaume (2004) presents an experiment with three different external cost valuation methods. This experimentation highlights the difficulty in pricing the impacts, as "the most comprehensive method monetizes less than $10 \%$ of the flows of the industrial process studied" (p. 443), with external costs varying "by a factor of more than 1 to 12,000 per unit of product" (p. 443). Added to the uncertainties of the quantification of impacts themselves, this makes monetization a perilous exercise (Bebbington et al., 2007).

Secondly, FCA is criticized for increasing efficiency but not sustainability (Milne, 1996). In all cases, sustainability is considered as an extra cost rather than as an added value that could be fostered by the organization. In line with this vision, the accounting models focus on showing how the organization failed to choose the least sustainable option. While they can be useful to identify less damaging solutions, they do not drive the organization towards sustainability but rather towards a lower level of unsustainability. This being so, they do not challenge business as usual.

The Sustainability Assessment Model (SAM) and multi-capital accounting methods are affiliated with full cost accounting. However, they differ by a singularity that has consequences on accounting for sustainable development: they do not account only for negative externalities, but also positive ones, which was not the case in earlier FCA experiments. The City Farm experiment also differs from FCA as it does not monetize impacts.

\subsubsection{Accounting for sustainable development: The City Farm experiment}

In 2000, Lamberton developed accounting for sustainable development for a case company called "City Farm" without using the monetarization phase. He used the framework of eco-efficiency and eco-justice, with the three dimensions of sustainable development that he measured through five performance factors. His model extended beyond the organization's financial entity to include what he called second- and thirdlevel impacts. He defined achieving ecological sustainability as the basis for financial sustainability. Environmental performance was measured in physical terms, and given both an efficiency target and a sustainability target (for example eliminate waste or switch to non-polluting renewable energy sources). The gap between actual performance and sustainability performance is the organization's degree of unsustainability. Lamberton (2000) acknowledged the difficulty in calculating the "carrying capacity", which would require regional level data over the long term, in obtaining the impact of the organization on the erosion of the stock of natural capital. Moreover, he recognized that "there is an inherent difficulty in applying the objective of ecological sustainability to individual organizations" (Lamberton, 2000, p. 601).

\footnotetext{
3 First tested on their Puma brand in 2011, Kering made their methodology public in 2013 and is now publishing the E P\&L of all their brands. Several other companies have followed this path (including Novo Nordisk in 2014, Philips in 2017 and Natura).
} 


\subsubsection{Sustainability Assessment Models (SAMs)}

A SAM is a form of full cost accounting developed in the United Kingdom by BP with Jan Bebbington (2007). It was built to allow BP to understand more fully the concept of sustainability within the context of a single project, as a decision-making tool. A SAM is intended "to facilitate the consideration of sustainability issues in arenas where economic rationalism dominates management decisions, and make the subjectivity and assumptions associated with monetization explicit" (Frame and Cavanagh, 2009, p. 198). There are several key differences between a SAM and an FCA. First, the case studies of SAMs have demonstrated that stakeholder engagement within the process is critical to the success of that technology. Second, the categories used to measure impacts are different from past FCA experiments. They include economic, resource use, environmental and social impacts. FCA considers economic impact only through a diminished profit (E P\&L) or value added (BSO/Origin), while SAMs look at the economic category separately through its benefit (for example the project's contribution to GDP). Finally, a SAM may include benefits such as improved quality of life, providing mobility services or improved biodiversity, which FCA does not.

The result of a SAM is presented visually through a "sustainability profile" for a given project that may be used to compare and communicate the relative sustainability (or unsustainability) of different options (Frame and Cavanagh, 2009).

\subsubsection{Multi-capital accounting approaches}

After the momentum gained by the IIRC integrated reporting framework (2013), several organizations developed tools similar to the SAM, which can be gathered under the banner of "multi-capital accounting approaches". Crown Estate was one of the first companies to develop and publish their "Total Contribution" in 2013, while KPMG was one of the first Big Four companies to publish their "True Value" methodology in 2014 (Hendriksen et al., 2016).

The approach within these models is usually based on weak sustainability, and a risk approach to "protect future value" (steps 2 and 3 of the True Value model). In the particular case of the True Value Methodology, the underlying definition of capital is that of a group of assets necessary to the organization's functioning that need to be monitored and preserved. Therefore, True Value allows an organization to quantify "potential risks to earnings through reduced revenues, increased costs or increasing investment" (KPMG, 2014 , p. 48). In this configuration, the natural capital is part of the organization's wealth, regardless of other stakeholders' interests in these natural capital elements. In that respect, they can be subjected to Gray et al. (1995, p. 232) criticisms of environmental accounting positioned "within the strict confines of conventional accounting, then we can expect [...] a very narrow, tamed, safe and controllable conception of environment to be created by the accountants of the environment". We can thus consider that they fail in challenging the "business as usual" assumption. 
Moreover, the True Value model ${ }^{4}$ uses monetization to compare and bring together items as different as GHG emissions, water extraction, and human health deterioration. Indeed, the final result of multi-capital accounts is often one single monetized value, i.e. the value created or destroyed by the organization over the three capitals. This assumption that you can coalesce the different capitals is also based on weak sustainability.

\subsubsection{The TDL-CARE model}

In France, Rambaud and Richard (2015) developed an alternative model of multi-capital accounting named the TDL-CARE (Triple Depreciation Line - Comptabilité Adaptée au Renouvellement de l'Environnement - Accounting Adapted to the Renewal of the Environment) model. This model considers capital as a liability, to be maintained. Their integration of natural capital is also monetary, but they account for the maintenance of the different capitals.

The TDL model itself is based on six assumptions, the first one being that "three types of resources are capital from a social point of view: financial, human, and natural" (Rambaud and Richard, 2015, p. 100). The repeated use of these capitals implying their degradation, and the firm being recognized as responsible for it, its financial statements should encompass the costs related to the mitigation of their degradation. In line with these assumptions, the TDL model introduces the calculation of maintenance costs by inscribing the historical cost depreciation of human and natural capital into the global financial accounts of the organization (Rambaud and Richard, 2015). The calculation in physical values of the human and natural capital is not directly visible in the approach. The sustainable levels of impact (thresholds) and the correlated actions needed to be sustainable are to be determined through stakeholder collaboration. The costs of these actions are then integrated in the firm's (financial) accounts.

While this model uses concepts linked to strong sustainability, such as the maintenance of capital (Gray, 1992) and the notion of capital as a liability (a burden, according to Birkin, 1996), it does not go beyond the financial boundaries of the economic entity on which the calculations are made (while accounting for sustainable development clearly indicates the need to see the entity as nested within a system of interactions, and the natural ecosystem). Moreover, it is blind to the physical reality of the maintenance it advocates for, by focusing on financial maintenance costs.

\subsubsection{Accounting for sustainable development: what is still to be done?}

While we can see from the review of the different accounting methodologies and their past experiments that sustainable development has been partially embedded into multiple tools, none of them has managed to "account for sustainability", though several illustrate accounts of unsustainability (Bebbington and Gray, 2001; Lamberton, 2000).

Moreover, they do not manage to question business as usual. In the FCA attempts studied, sustainability is viewed as a cost rather than an extra value generated by the organization. According to this logic, models and communication tend to show that the organizations

\footnotetext{
${ }^{4}$ All other recent multi-capital accounting models such as Crown Estate, Olam, Value to Society from BASF, Holcim-Lafarge, Yorkshire Water do the same.
} 
did not apply the most unsustainable option available. While they enable less detrimental solutions to be identified, they validate choices already made towards reducing unsustainability. They do not, in that respect, question business as usual. This is also true for KPMG True Value, built around the idea of risk management in a weak sustainability frame. Here again, business as usual is barely questioned. We propose a new model based on four main strong sustainability concepts to further our understanding of accounting for sustainable development. The design is discussed within the findings section.

\section{Research Design}

We conceive engagement research "as the urgent response to the social and environmental crisis and the exploitative nature of operations by most organizations with regard to society and the environment" (Adams and Larrinaga, 2007, p. 340). Therefore, this research has been designed "with a primary focus on the achievement of sustainable development (...), recognizing that a penetrating analysis of the lived experience of sustainability accounting is needed to initiate our understanding of the transitions toward organizations with a more positive impact on sustainability" (Adams and Larrinaga, 2019, p. 3). It is based on intervention research by the first author within a business organization. We now present the research setting and project origin.

\subsection{Research setting}

The research was conducted in a medium-sized logistics company that is the servicing organization for a retail coop specializing in organic food and ecological products. It is jointly owned by the retail shops and 20 agricultural cooperatives that supply part of the products sold by the retail network. This cooperation between food producers and retailers brings stakeholders together around a common goal: to develop organic production in France "in a spirit of fairness and collaboration, with strong ecological expectations". This ecological and political ambition started in the '70s with the creation of the first consumers' coops when organic products were difficult to come by. Today, the company has more than 1000 employees and a turnover of above $€ 500 \mathrm{M}$. It has furthermore defined itself in its strategy as "militant and recognized as such".

Despite its ambition to be exemplary in all aspects of Corporate Social Responsibility (CSR), the continuous double-digit growth rate leaves little room for groundwork on that subject. Its control system consists mostly in operating accounts, reviewed on a monthly basis by the board of directors. An ecological scorecard, reviewed once a year, exists but it is not monitored by the board of directors. Its aim is to supply yearly data for the regulatory annual CSR report.

\subsection{Origin of the research}

The research project originated in the observation of discrepancies between the values and objectives professed, and some of the actual decisions made. As a "militant coop", the general director insisted on the fact that business profits were not expected of him, but rather the implementation of strong social and ecological actions representative of an ambitious CSR strategy. Despite this statement, it was observed in 2012 and 2013 that cheaper solutions more detrimental to the environment were chosen: the action plan to reduce GHG emissions was revised to next to nothing to avoid labor expenses and 
financial investments. While promoting a green electricity provider and communicating on the company's switch to a $100 \%$ green electricity mix, for example, the company decided not to use it on four out of six sites to reduce costs for two more years. Meanwhile, it was experiencing double-digit growth rates and its highest net incomes so far. As a servicing company for the coop, it is not expected to generate high net incomes.

The first author's motivation in working for this company was the possibility of developing business solutions aligned with a strong sustainability approach. Previous proposals from the researcher to help integrate sustainability into the company's decision-making process (such as the integration of sustainability principles in its strategic choices) had been rejected. Other direct approaches during meetings aimed at convincing the general director to act on the results of a primary CSR evaluation were met with defiance. They seemed to be interpreted as a questioning of his decisions.

Because an up-front discussion on the topic of sustainability was not received positively, the first author developed an approach embedded in a research project. The idea was to design a strong sustainability-based accounting tool that would be used to evaluate the organization's operations. If the directors were to use this tool, it could steer their behavior towards more sustainable choices by providing feedback on their decisions not from a "biased" person, but from an "objective" tool that was perceived as neutral.

In 2014, the first author proposed the project embedded into a PhD. Positioning it as a research project disconnected it from the daily running of business, making it less political (at the time, CSR was territory jealously guarded by a single person), and more easily perceived as the "researcher's project" that could potentially be useful, but did not appear to question business as usual yet. Finally, agreeing to finance a PhD on sustainability management control was in keeping with the general manager's selfattributed role of CSR champion. The research proposal did not question his champion role, which the researcher's previous proposals had probably been perceived as doing. On the contrary, it was perceived as potentially reinforcing his image of CSR champion.

The researcher's project was met with interest by two actors in the organization: the CSR manager, recently recruited and appalled by the lack of performance culture in the organization, and the management control director, who had recently encountered difficulties in implementing a balanced scorecard with the board of directors. She saw the research project as a way of obtaining a management control tool to manage resources and show how today's economic decisions help achieve objectives. Opting for an accounting tool rather than a scorecard was for her a way of measuring what was anticipated to be better societal value creation and the environmental advantage of decisions that were less financially optimal. She defended the research project in front of the general manager, who accepted it. This implied the allocation of $30 \%$ of the researcher's working time on the PhD for four years, starting in November 2014. The beginning of the research was spent on preliminary research work. The actual work on the tool described in this paper took place between March 2016 and December 2017. The tool to be developed was identified by the sponsors as innovative and in keeping with "the organization's DNA" for its pioneering side and support of sustainable development. Despite that acknowledgment, the research project was not included in the organization's management system and was managed separately from the company's standard activity. 


\subsection{Co-construction of the sustainability accounting tool}

The research involved three groups of actors, with different levels of engagement and time dedicated to the project. The first group was composed of the two project sponsors, who gave the researcher regular feedback (every three months on average) during the year on the tool's development. The feedback concerned how we presented the three capitals approach and how they understood it. It also covered a review of the calculations performed. The second group was composed of voluntary members of the board of directors, who took part in three meetings. The last group consisted in various members of the company in charge of collecting activity data. These people participated in data collection for the tool over short periods of time, when documented data were not directly available in the company's information system. Indeed, engagement research is a "humble exercise of a form of science that does not speak from a hierarchical and distanced position but does assume that knowledge about SEA (social and environmental accounting) tends to be generated in the context of application and assessed by a broad set of actors in society" (Correa and Larrinaga, 2015, p. 9). While this research was initiated and conducted by the main author of this paper, it was not a lonely exercise. It involved a broad group of organization members in addition to outsiders such as the $\mathrm{PhD}$ thesis director, and a TDL-CARE research group who participated in the theoretical discussions, as well as discussions about the model through academic conference interactions.

\section{INSERT ABOUT HERE TABLE 1}

\subsection{Data collection and analysis}

Our primary data source lies in the research intervention project. In choosing an intervention research design, we respond to the gap in research highlighted by Adams and Larrinaga-Gonzalez (2007, p. 334) : "One of these research avenues might be to engage with organizations to examine processes of [...] sustainability accounting and accountability, and the manner in which these processes, the data collected and subsequent reporting impact on performance." Our initial motivation was definitely aligned with their conception of "engagement research as the urgent response to the social and environmental crisis" (p. 340).

Intervention research allows experimental research to take place, creating both organizational development and new knowledge (Plane, 2000). The latter is often generated in the context of application (Correa and Larrinaga, 2015). Intervention research's particular feature is that researchers actively work with the organization and propose alternatives to current organizational undertakings (Correa and Larrinaga, 2015; Jonsson and Lukka, 2007). In some cases, such as Bebbington and Gray (2001) and Antheaume (2004), experiments tend to focus more on the technical issues and the researcher's perspective on the experiment (Correa and Larrinaga, 2015), particularly when they are the subject of academic papers. This paper also focuses on the technical aspects of the model proposed and tested in the organization, with a researcher's perspective on accounting for sustainable development.

The principal objective of intervention research is to gain an understanding of the functioning of a social situation (Hastrup, 1997), through "the critical and humble 
participation of researchers in the organizational and social contexts in which SEA is practiced and experimented" (Correa and Larrinaga, 2015, p. 8). Through first hand access to nontraditional yet important information such as "organizational gossip" (Soin et al., 2002), intervention research can yield insights on "the technical and political difficulties that the application of (accounting for sustainable development) implies in the organizational context of application" (Correa and Larrinaga, 2015, p. 8).

Doing insider research facilitated data collection (Larrinaga-Gonzalez and Bebbington, 2001) but made time outside the organization even more necessary to avoid overinvolvement, in our case "staying native" (Collier, 2001). This was achieved through monthly half-day meetings with the second author of this paper. These meetings provided the opportunity to question the insider's observations and bring distance between her and the field. This was complemented by engagement with the research population through participation in research workshops and conferences (once to twice a year for the past three years), as well as three working sessions with TDL-CARE researchers during the last year. Finally, the last eight months were spent outside of the organization to facilitate detachment.

\section{Findings}

\subsection{The sustainability accounting model}

The sustainability accounting model we propose is a multi-capital accounting model based on three capitals (economic, social and environmental), although only two are being discussed in this paper (social and natural). The omission of further elaboration on the economic capital in this project is analyzed in the discussion. All the calculations are in non-monetary units (for social and natural capitals) and based on indicators that evaluate to what extent each type of capital's resilience conditions is maintained. Year after year, the calculation will include "maintenance" activities that result in recovery of system conditions, so the destruction of the stock of capital could be lowered, halted, or even brought back to a sustainable level (within planetary boundaries). According to Gray (1992), a sustainable organization is one which keeps its capital intact. Therefore, "from an accounting perspective the tracking of capital flows could provide some idea about the extent to which the organization is moving towards or away from sustainability" (Bebbington and Gray, 2001, p. 562).

The goals behind development of the tool were as follows. The first one was to get the managers used to working with environmental, societal and economic factors simultaneously. The second one was to get them to question the role and place of organizations in society, and possibly revisit the company's mission. The third goal was to give them a way of evaluating the relevance of their decisions after these conceptual shifts. The current measurement of performance being mostly financial, the aim of this accounting tool was to provide balancing renditions of performance on natural and societal capital, leaving the paradoxes visible.

We will now develop the tool's external framework, which is multi-capital (representing the three main capitals) and mimics financial statements. 


\subsubsection{From financial accounting to a multi-capital accounting model}

Given the focus on financial performance in the organization, the first author was looking to bring a more complete view through a new rendering tool. To improve its chances of adoption, this work was embedded in the formalization of the company's CSR work, which was putting an emphasis in the organization's discourse on the "three pillars of sustainable development: financial, environmental and social". Merging this trending vocabulary with familiar structures, the first author decided to build a multi-capital accounting tool that would add more decision-making elements to financial performance. It was decided to present three accounts as three complementary pictures of the organization so as to encourage a broader view of performance that is more compatible with the organization's mission.

\subsubsection{The three capitals}

Building on the CSR trend in the organization, the first author introduced a framework that she considered more aligned with strong sustainability. She decided to use the approach introduced by Passet (1979), which describes the physical relationship of three spheres by representing them as "nested and interdependent" (Natural Step, 2010).

\section{INSERT ABOUT HERE FIGURE 1}

According to him, economic activity exists inside the sphere of society, which in turns relies on the biosphere (nature) to exist. Therefore, an organization relies on the three spheres to exist. With intense interactions inside and between the spheres, strong sustainability implies that each sphere needs to be maintained for the organization to be sustainable. Each sphere corresponds to a capital that the organization depends on and should maintain. Consequently, we consider three capitals ${ }^{5}$ : natural, social and financial. Social capital covers both human and social capital; it is the "society" system that needs to be maintained.

\subsubsection{Mimicry of financial accounts}

It was considered necessary to use a technical substrate usually restricted to financial data for all three capitals in order to illustrate that the same level of attention needed to be given to social and natural capitals as to the financial capital. Consequently, the model consists in an accounting package with a balance sheet and profit and loss accounts. In this respect, it fits in with Birkin's (1996) idea of a "balance sheet [that] would include scientific assessments, social reports and aesthetic judgements as well as economic measures. Such an account would seek to explain critical issues as fully as possible." (Birkin, 1996, p. 249). While mimicry could be considered as going against the principles of strong sustainability, it is a much-used pragmatic artifact that serves the purpose of legitimization, aiming to raise the importance of sustainability to the same rank as that of financial accounts today (Bebbington et al., 2007; Etzion and Ferraro, 2010).

\footnotetext{
5 Today, multi-capital accounts often base their models on more capitals, considering the IIRC six capitals, which are assets. Capitals such as social versus human, or "health" (Danone), cultural capital (Vivendi), manufacturing and intellectual capitals are used because the models consider them as resources used by the organization, not as a liability (debt).
} 


\subsubsection{The choice of non-monetization}

Unlike many of the models presented in the literature review, we did not monetize impacts because we believe that monetization commodifies nature, thus running the risk of "placing (nature) into the very system of marketisation that is partly responsible for destroying them" (Coulson et al., 2015, p. 306). We also refuse to synthesize the maintenance obligations into financial values that would lead to a single account (with a single number), which is what Bebbington and Gray (2001) did by monetizing sustainability costs. We use separate accounts for each capital as complementary images of the organization. This method ensures that the impacts remain visible, impacts being capital losses linked to degradations that could not be properly mitigated. This clearly illustrates the debt incurred by the organization towards each capital. In this respect, it is an illustration of the unsustainability of operations through the level of debt for each capital.

\subsection{Accounting for sustainable development: concepts underpinning the sustainability accounting model}

The tool was designed around four key concepts, all linked to the desire to embed a strong sustainability vision of sustainable development in accounting: capital as a liability, sustainability as a resilient system, an extended scope of accountability and the carrying capacity of our planet. While this new tool is not an experiment implementing any of the past models, it does build on concepts that were used and tested in the past, including maintenance, thresholds, and the need to account for the value chain. It also tests embedding new concepts into accounting, concepts such as a systemic approach to capitals and their resilience and envisioning a capital as a liability rather than an asset.

\subsubsection{Capital as a liability and the maintenance concept}

The use of the notion of "capital" within accounting for sustainable development is not without criticism. According to Coulson et al. (2015, p. 291): "There is division within academia, accounting in particular, on the appropriateness of applying the term capital beyond finance and economics to social issues and nature". Criticisms include the fear of capture by economic hegemony and a loss of morality (Coulson et al., 2015; Martineau and Lafontaine, 2019). Moreover, it implies the possibility that nature (natural capital) is owned, and can be bought and exchanged using money. The current use of the term "capital" is based on the economic assumption that capitals are "assets" to be managed (Barbier, 2019): This engenders the notion of "appropriation" of nature.

In this sustainability accounting model however, we use a different notion of capital, which refers to the notion of "debt" or "burden" (Birkin, 1996). Natural capital is seen as a liability (Richard and Rambaud, 2015) or a debt; in other words, an element "to be maintained". This is also a key element of strong sustainability, which requires natural capital to be kept above a certain threshold (Noel and O'Connor, 1998).

By considering capital as a liability we embrace the concept of maintenance used by Gray (1992), and Gray and Bebbington (2001). The concept of "maintenance" was also used in 
the costing method of the FCA experiments of BSO/Origin (Huizing and Dekker, 1992) and Interface Europe (Howes, 2000). In this approach, the capital to be maintained requires an approach in keeping with the characteristics of liabilities rather than assets, which can be renewed.

\subsubsection{Systemic nature and resilience of sustainability}

Gray and Milne (2004) insist on the fact that sustainability is a systems concept. System thinking has not yet been implemented in models. While integrated reporting (IIRC, 2013) and connected reporting (Accounting for Sustainability, 2007) allude to the idea of interactions and trade-offs, their implementation in practice has clearly avoided processing system thinking within reporting. "Theories and approaches to environment and resource management have to a large extent focused on single issues or resources and been based on a steady-state view, interpreting change as gradual and incremental and disregarding interactions across scales" (Folke et al., 2005, p. 442).

A system-thinking approach implies that the economic activity is nested within and interdependent upon the social and environmental spheres, which thus implies an interconnectedness with its value chain and the accounting of secondary effects. It also implies that each capital be considered "as a whole" (and not as a sum of specific elements). In all the approaches described in the literature review, the constituents of natural capital are defined by the organization's activity, whether revolving around its need for resources or the elements of natural capital it must maintain to survive as an economic entity. However, capitals in our model are not defined by singling out specific items or services but through their nature of resilient systems. "In the resilience rationale, the aim is to manage a system's capacity to avoid or handle regime shifts that impede its continued functioning" (Hoekstra et al., 2018). Maintaining this capital implies respecting the conditions under which the system retains its capacity to "change in order to maintain the same identity, that is its capacity to absorb disturbance and reorganize while undergoing change so as to still retain essentially the same function, structure and feedbacks" (Folke et al., 2010, p. 3).

However, operationalizing the concept of resilience is difficult. Godard (2004) explains that it is not a question of "freezing" the environment, but of retaining its basic functional organization and its ability to evolve in a way that preserves its regulations and a sufficient diversity of the resources it houses. It does not involve stock measurements or specific components concentrations monitoring for themselves, but rather evaluating to what extent the principles ensuring continued resilience are respected.

\section{INSERT FIGURE 2 ABOUT HERE}

The model's principles had to be general enough to represent all the ecosystems (see Figure 2). We used the eight sustainability principles (SPs) that contribute to the formulation of the Framework for Strategic Sustainable Development (FSSD) (Broman and Robert, 2017). The first three principles, tackling environmental sustainability conditions, were introduced at the end of the '90s (see Holmberg and Robert, 2000). They are not used to describe natural capital, but rather the conditions that are necessary and sufficient to ensure its preservation. The next five principles for social capital are more recent (Missimer et al., 2017). They identify societal conditions to respect when 
sustaining essential aspects of "complex adaptive social systems" (Missimer et al., 2017, p. 36).

\section{INSERT TABLE 2 ABOUT HERE}

The Environmental Sustainability Principles (ESPs) were defined to maintain the natural environment's resilience. In order to link the definition of capital maintenance principles with accounting, it is necessary to identify measurable proxies for each of the principles. These proxies make it possible to track the impact made on each of the capitals, and measure how the company reduces or increases its debts towards each capital. The higher the impact without mitigation, the higher the debt. A systematic increase in the impact of one sustainability principle (as can occur if there is an increase in the organization's activity without decoupling) is a definite sign of failure in conserving the capitals.

\subsubsection{The embedded organization: the need to account for the value chain}

According to Bebbington and Larrinaga (2014, p. 406), "financial accounting contributes to the construction and maintenance of a bounded organization that ignores its full character". Therefore, we extended the scope of analysis to include the impact of the products bought and sold by the organization within the considered scope, an accounting scheme that goes beyond the boundaries of the financial entity. This is consistent with a strong sustainability view. In order to exemplify the difference in control level between "purchased" impact and operated impact, we elected to split the Profit and Loss accounts in two: one for transaction goods, and another one for activity. We anticipated this separation to facilitate the analysis of results by members of the organization.

\subsubsection{Thresholds for sustainability}

According to Milne (1996, p. 152), "sustainable outcomes require the rationing of scarce ecosystem capacities". Rockström et al. (2009) and Steffen et al. (2015) have been working on establishing planetary boundaries for a safe operating system for humanity and have now identified nine of them. While this work aims to define limits on characteristics deemed sufficient and necessary to ensure resilience of the natural environment, no method has yet been formulated to calculate a threshold for an individual organization ${ }^{6}$, with the exception of the recent experimentation known as the Science Based Targets Initiative, which focuses on GHG emissions ${ }^{7}$.

Therefore, when tracking an activity's impact and linking it to the sustainability of its environments, we need to apply the concept of thresholds within current organizational accounting. Since no thresholds exist, the sustainability principles have to be applied to

\footnotetext{
${ }^{6}$ Reporting 3.0 (now R3.0) recently established a working group to operationalize planet boundaries (Global Thresholds \& Allocations Council, available at https://reporting3.org/gtac/), and Raworth (2017) has defined "social foundations" through her "doughnut economics" principles. Despite intensive work on thresholds, including on water by the WWF, there are very little operationalizable thresholds, especially for small- and medium-sized organizations.

7 To date, according to the Science Based Targets Initiative website, only 232 companies have approved targets, showing the difficulty of this process, mainly driven by big multinationals (August $6^{\text {th }} 2019$ ).
} 
ensure that no further degradation of the capital is generated. This is achieved by avoiding any systematic increase in the measured impact compared to a baseline consisting of the impact at a given time. Unfortunately, if the baseline is calculated when the capitals are already degraded, there is no guarantee of being able to maintain the capital. It is hence necessary to consider complementary actions to "correct" the effect measured in the baseline. The first evaluation carried out with the tool becomes the baseline. The values represent the initial capital, the debt contracted by the organization. The operationalization of two key concepts of SPs- "systematic increase" for the ESPs and "structural obstacles" for the SSPs (see Table 3) -consists in comparing the organization's impact with the initial baseline in the following years. The capital is considered to be maintained if no systematic increase in the organization's debt toward each type of proxy capital is observed.

Bebbington and Gray (2001) operationalized sustainability through four levels of possible maintenance activities, while Lamberton (2000) designed sustainability targets (in comparison with eco-efficiency targets). None of them considered their option provided the perfect iteration for the issue of contextualizing sustainability accounting within the overriding problem of the Earth's limited carrying capacity. Because the principle of "allocation" and the definition of a global sustainability level is either difficult or impossible, a recent approach developed by the NGO Future Fit on the basis of The Natural Step has involved developing break-even goals for companies to apply, similarly to what our model was trying to achieve ${ }^{8}$ (Future Fit, 2019).

\section{INSERT ABOUT HERE TABLE 3}

\subsection{The theoretical functioning of the tool}

We will now turn to a theoretical example of how the tool functions. For each proxy of capital maintenance, we define a baseline (year 0 ) which corresponds to a specific measurement for a given type of environmental impact. This measurement is based on data from the company's activity for a given year, called year 0 .

\section{INSERT ABOUT HERE TABLE 4}

For the subsequent years, we compute the difference between the impact measured each year and the baseline. If the measurement for a given impact increases from one year to the next, it means that the organization is depleting a specific category of the capital's resilience capacity and that its debt is increasing. If, on the other hand, the measurement for a given impact is lower than during the baseline year, it means that the company is respecting the sustainability principle through this impact. Therefore it would be more accurate to say that we have a balance sheet for each proxy of the maintenance of a given capital's resilience. For each dimension of natural capital, debt increases or decreases based on the difference between that year and the baseline year. To be sustainable, an organization needs to comply with all of the sustainability principles for all of the proxies. There are as many different balance sheets and debts as there are proxies. The balance sheet measures the level of debt at a given date. The P\&L account measures by how much debt has evolved over a given period of time. However, contrary to a classical financial

\footnotetext{
${ }^{8}$ See their website: https://futurefitbusiness.org/explore-the-benchmark/
} 
accounting approach, it is not desirable for the total of the balance sheet to increase. Indeed, organizations should aim not only to limit their debt, but also to remediate their initial impacts (the baseline). Here the logic is not "more is better" but rather "less is better".

The following table exemplify this evolution. The company in our example experiences a growth of $10 \%$ per year and does not make any major modification to its economic model or its operational choices. The tangible assets portfolio also increases by $10 \%$ in order to support this growth. The change in the accounts for proxy A is presented in Table 5.

\section{INSERT ABOUT HERE TABLE 5}

The income statements present the variation in the impacts measured via proxy A. They do not present a profit, but losses corresponding to the increase in the impacts. These are recorded as liabilities on the balance sheet i.e. as a negative result, which is accompanied by the recording of a debt towards this dimension. The activity does not appear to comply with the principle of sustainability of the natural capital represented by the proxy measured, since we are witnessing a systematic increase in this specific type of impact.

\subsection{Step-by-step implementation process}

We will now describe the implementation of the sustainability accounting tool step by step, as actually carried out within the organization. The first step was to choose the capitals and the proxies; the second step was to define the boundaries of calculation; the third step involved collecting data and making calculations. We then provide an example of real-life calculations for the organization.

\subsubsection{Choosing how to account for the capitals}

For the natural capital, we applied the sustainability principles, which served as guidelines to maintain the system's resilience. In order to evaluate to what extent the organization complies with these principles, we use proxies, which are environmental impact assessment indicators. These proxies-calculated using Life Cycle Assessmentswere already familiar to the organization through previous eco-design projects based on LCA. These indicators were selected depending on their relevance, on method robustness and data availability, and on their compliance with the planetary boundaries defined by Rockström et al. (2009) and Steffen et al. (2015). Table 6 presents the proxies associated with each principle.

\section{INSERT ABOUT HERE TABLE 6}

There was, however, no previous experience within the organization of measuring social capital. Consequently, we decided to involve the company's senior management in defining the proxies. We proceeded as follows: following a presentation of the research to the board of directors, volunteers were sought to take part in this capital co-analysis. Out of the ten members, five volunteered to participate. They received an eight-page preparatory document presenting various definitions of the capitals in a sustainable society. During an initial two-hour meeting, they then helped identify company activities 
that were relevant for monitoring social capital. A second meeting was organized a month later to present the results of their first work session and clarify some previously illdefined points. In collaboration with the sponsors, we then shortlisted some of the proposed proxies in order to build a coherent measurable system that was in line with the SSPs presented previously. Lastly, the project sponsors introduced a final dimension separate from the SSPs: the relationship continuation dimension, designed to represent the sustainability (through their duration) of connections with the stakeholders (employees, suppliers, members of the coop (the company's direct customers), and partners). These iterations resulted in seven proxies for social capital, presented in Table 7.

\section{INSERT ABOUT HERE TABLE 7}

Finally, the conditions for conserving financial capital were not studied. In this respect, we followed the example of the previous experimentations previously identified, which do not measure or question the way financial capital should be operationalized in a multicapital accounting tool either. While we acknowledge that this may be subject to discussion, the choice was made to focus on the other two capitals during our experiment.

\subsubsection{Boundaries of the calculations}

In line with ISO 14040:2006 guidelines (ISO, 2006), we considered the entire life cycle of the products, and defined the system boundaries in line with the analytic goal. This avoids reducing an organization's impact at the cost of increasing that of another actor in the chain, which would only lead to global unsustainability.

In our experiment, the scope ranges from the extraction of raw materials to end-of-life packaging inclusive, but sale and usage were excluded due to the organization's low impact and visibility in these stages. These limits need to be tailored to the organization's activities. We retained the life cycle perspective for both natural and social capitals.

To ensure the visibility of elements directly linked to the company's activity and those linked to its transactions, we created two levels in the profit and loss account: one dedicated to the company's direct activity, and the other one to the goods sold.

\subsubsection{Data collection and calculations}

In order to realize this environmental impact appraisal, two types of data were used. The first type focused more specifically on the organization. Data for the environmental impact calculation were extracted from the organization's most recent carbon footprint and from its environmental scorecard. LCAs were performed using Simapro software ${ }^{9}$, most of the time using an existing impact factors database for French or global average items. To calculate ecosystem burden, Birkin (1996) considers eco-balance accounts to be an appropriate methodology. This is also how impacts are calculated for FCAs, multicapital accounts or the GRI indicators.

\footnotetext{
9 Simapro is the trademark of the leading LCA software (available at https://simapro.com/, accessed August 6th 2019).
} 
The second type of data was linked to the impact of transaction objects. The company sells about 8,000 references supplied by more than 600 suppliers. After extracting quantitative and qualitative descriptions of the products (mostly food items), we proceeded to identify the necessary LCA, knowing that the calculation of each individual reference would not be feasible in the available time (six months). We selected the $20 \%$ of reference families that represented $80 \%$ or more of the sales volumes for each type of goods sold. Based on the sales data, we defined a prototype product representative of each reference family. A Life Cycle Impact Assessment (LCIA) ${ }^{10}$ was performed for each prototype, and the impact extrapolated to the total volume of the family it represented.

Data for the social capital, on the other hand, came from various sources: annual CSR and social reports, the supplier database, the cooperative's network management department's scorecard, the partnership management department's scorecard, and for the oldest partnerships, the organization's history. This enabled us to calculate the baseline linked to the organization's direct activity. Unfortunately, we were not able to retrieve social data for the assets and transaction objects, making this account incomplete.

While the general composition of the social capital and the SSPs had been identified, their operationalization led to unavoidable simplifications when applied to a specific organization. For example, the "structural obstacles" mentioned in the SSPs are not directly measured in the model. Instead, the same rule as for the ESPs is applied, namely that an increase compared to the baseline is a sign of a structural obstacle needing to be removed. Moreover, while ESPs have been extensively tested during the last 25 years (Missimer et al., 2017), SSPs were presented only in 2017 to address the need to further develop the previous "social dimension of the FSSD". They still "need testing and adjustment over time" (Missimer et al., 2017, p. 50). Considering this, the principles selected in this model consist in the gathering of the SSPs and one additional dimension identified by the organization's members as a societal capital. They are intermediary options to test the model, still to be refined and discussed.

\subsubsection{Results}

Given the data available, the environmental calculations were more advanced than the social ones. Baselines were calculated for both capitals, albeit partially for the social capital. Table 8 shows the evolution of the environmental proxies for two years with $5 \%$ growth. This systematic increase is synonymous with unsustainability.

\section{INSERT ABOUT HERE TABLE 8}

\subsection{Using a strong sustainability accounting tool to question business as usual}

One of the main contributions of the tool was to question business as usual by representing the impact of growth on the capitals. Without decoupling, an increase in activity represents an increase in impacts, which is contrary to sustainability principles. In such a context, the system's resilience cannot be maintained, and the organization's activity is not sustainable.

\footnotetext{
${ }^{10}$ A Life Cycle Impact Assessment refers to the third phase of the full LCA and addresses the evaluation of
} environmental impacts. 
The system approach makes it necessary to evaluate the organization's activity in relation to its competitors. Is one company's growth equivalent to another one's decrease in activity? How do rebound effects impact the global volumes (Binswanger, 2001)? Are competitors' impacts lower or higher than those of the studied organization? However, a single organization cannot answer these questions. Consequently, the conservative approach to be sustainable is to actively decouple growth from impacts.

While the sustainability accounting tool enabled the researcher to demonstrate the organization's unsustainability, this was not the result expected by the organization. Being positioned in the "green" economy sector, management had difficulty understanding how the measurement approach could lead to a negative result that would have them rethink their current model.

\section{Discussion}

We used an intervention-research project in a sustainability-inclined French coop to trial the design and implementation of a sustainability accounting tool. We identified how accounting tools designed for strong sustainability deliver accounts of unsustainability and how this characteristic influences the possibility of their adoption by organizations.

Through this research project, we were able to address the issue of how accounting for sustainable development remains a daunting task, illuminating the difficulties of applying concepts of strong sustainability to an actual accounting tool (Correa and Larrinaga, 2015; Antheaume, 2004). We will now reflect on the limits of the accounting tool and the consequences of the conceptual model on its non-adoption, on options to continue working on and with this model, and on intervention research as a design for accounting for sustainable development.

\subsection{Limits of the model}

As stated in the introduction, we propose this model as another "interim solution" (Correa and Larrinaga, 2015) for accounting for sustainable development, recognizing that it is difficult to translate radical insight into a sustainability accounting tool (Gray, 1992).

First, we recognize that while we have endeavored to implement a system view of sustainability and to account for the resilience of capitals, these principles remained invisible within the accounting tool, which used calculations and indicators similar to those of traditional tools such as the GRI. Therefore, without the knowledge of the sustainability principles and an understanding of the conceptual basis used, this tool could be misused and become just another impact measurement tool.

Second, one might question the choice of using the term "capital", and the mimicry of financial accounts while having based this tool on strong sustainability. As previously explained, capital is not used here to define nature as an "asset" but rather as a "liability". However, we understand that using financial accounting terms and visuals might lead to the same capture that we are trying to denounce through this experiment. One alternative 
is to build a strong connection between the "physical" underlying indicators and the potentially monetized capitals, for example through a dashboard to steer sustainable development. Often, tools that monetize make the "physical" indicators disappear, and thereby, the magnitude of impacts becomes invisible.

Third, we recognize this experiment's failure to integrate questioning of the economic capital. Indeed, as our goal was to build a sustainability accounting tool, the three capitals should have been accounted for together. While the accounting of the economic/financial capital is often left unquestioned (the IIRC business models published together with FCA and multi-capital accounting all use traditional financial measurements of finance such as profit, value added or return on investment), we believe the black box should be reopened, notably with the new B-Corps, mission enterprises and social enterprises developing in the future.

Fourth, we already discussed the difficulty in accounting for social capital, especially within the strong sustainability context. Though we used the social sustainability principles developed in 2017, there was no framework for social capital indicators to match these principles. The proxies for SSPs might not be optimal (including the number of meetings for one indicator), and we recognize that we could have furthered that assessment by using an existing list of indicators, such as the GRI indicators, indicators from the sustainability accounting standards developed by the SASB or the KPIs for ESG list by EFFAS. However, none are linked with strong sustainability and directly implementable within the context in which we were designing the tool. Further discussions on what kind of indicators represent strong sustainability assessment of social capital are warranted.

There are different sustainability frameworks that could have been used instead of the sustainability principles for the operationalization of this tool. For example, Sala et al. (2015) cite the Millenium Development Goals, the Planetary Boundaries and Agenda 21 as potential sources of sustainability principles. These authors then develop a framework to assess sustainability assessment models through boundary orientedness (whether they use thresholds or not), comprehensiveness (from one to three pillars), integratedness, stakeholder involvement, scalability, strategicness and transparency. The Natural Step theory meets several of those criteria, and could be considered a potentially eligible basis for accounting for sustainability. Moreover, The Natural Step has been said to be scientifically sound, notably with respect to its environmental concepts (Upham, 2000). One might add that planetary boundaries are not contradictory with using the sustainability principles. On the contrary, the boundaries can be used in conjunction to define the limits to use for each principle. The identification of a proper translation of global limits to individual organizations will enable an improvement of the model by freeing it from a dependence to the first year's calculations. This is what Future Fit has been trying to do in practice in the last few years.

However, some concerns have also arisen. Sustainability principles are accused in particular of being too rhetorical, making them subject to multiple interpretations and difficult to operationalize (Upham, 2000). Moreover, the precautionary principles embedded in The Natural Step are such that organizations will obviously breach their principles first. Similarly to Bebbington and Gray (2001), Upham (2000) proposes four 
levels through which those principles may be achieved (see Figure 3, p. 451). He also summarizes the advantages and disadvantages of The Natural Step in his Table 1, p. 452.

While there is no perfect sustainability framework, it is important when choosing one to accept working with the underlying concepts that make that framework a possible foundation for accounting for sustainable development.

\subsection{A non-adopted experiment}

As other engagement papers have also concluded, our sustainability accounting tool was not (to date) adopted by the organization, and did not therefore realize its potential (Adams and Larrinaga, 2019). However, we think that its failure to be adopted yields insights into the organizational operations and the role of accounting for this organization (Adams and Larrinaga, 2007).

First, the strong sustainability approach embedded in the tool makes it an example of accounting for unsustainability (Bebbington and Gray, 2001). Given the organization's activity, its sustainability is self-evident for its members. This is even more so when some less optimal economic choices are made for societal or environmental reasons (entrylevel salaries $15 \%$ above the French minimum in the first case, with a training budget above average, or ecological products and use of green electricity in the second case). The familiarity of the chosen structure (mimicking financial accounts) might not have been enough to compensate for the rationale of distance to unsustainability accounting for the sponsors and board of directors.

The second reason we hypothesize is linked to the discrepancy between the results, which measure unsustainability, and the expectation of the most influential sponsor, which was to bring a positive spin to the financial balance sheet: "In our company we penalize our net result because we use environmentally-friendly products, etc. and we don't show our investment in society. We create societal value and degrade the environment less. This is a way to have a positive balance"11. By contradicting this objective (the products amounted to most of the impact, and no comparison with conventional products was available), the baseline values diminished the rhetorical advantage of the accounting tool. To further advocate the model, it would be necessary to provide comparative calculations to validate the hypothesis of being less unsustainable than others. This would then enable the use of an "accounting for unsustainability" approach to generate narratives of sustainable choices.

Finally, we can conclude that this project was accepted because it was an "experiment" and "on the side". Working with the voluntary members of the board of directors and the sponsors enabled the main author to design the accounting tool and carry out the baseline calculation. While participating actively, the sponsors continued to consider this project as the researcher's rather than the company's. However ambitious an organization declares itself to be on the sustainability front, the introduction of a sustainability tool impacting all aspects of that organization's activity is met with the same challenges as any large-scale change in an organization: availability of resources, actors' buy-in, time constraints, shifts in priorities and so on. In the name of maintaining the organization's

${ }^{11}$ Excerpt from $21^{\text {st }}$ of July 2016 second working meeting transcript 
activity, all these factors actually jeopardize the endeavor seeking to insure its sustainability.

Despite this setback, we believe that this new experiment has "taken us closer to understanding both institutional and organizational specific impediments to SD" (Bebbington and Gray, 2001, p. 582). Moreover, this will lead to a better conceptualization of what a sustainable corporation might be (Bebbington and Gray, 2001).

The conditions for adoption of a tool accounting for strong sustainability remain to be defined. Further research is needed. We suggest, that the adoption of such as tool needs to be accompanied by a different kind of leadership, and change management, as well as a systemic approach to the results that the accounting tool will bring. Too often, accounting change is brought in isolation of the competitive and institutional arena in which the organization is encompassed, and in isolation of the radical changes potentially needed to its leadership and business model.

\subsection{Intervention research for accounting for sustainable development}

"This iterative process of working within an organization and then reflecting on the experimentation is also an attempt to understand more about the nature of accounting" (Bebbington and Gray, 2001, p.583). As a form of engagement research (Adams and Larrinaga, 2007), we believe that intervention research provides researchers with the opportunity of tackling the struggles of operationalization, adaptation and adoption all at once, interweaving the conceptual, technical, social and political, and institutional contexts.

On the one hand, this research design allows researchers to become agents of change, running the risk that they themselves change and become captured by the research process (Adams and Larrinaga, 2007). However, it is clearly the risk to be taken if we want to avoid becoming irrelevant academics (Adams and Larrinaga, 2007). On the other hand, this research design allows for dominant discourses and power relations to be unpacked, contributing to critical research in the role of accounting (Correa and Larrinaga, 2015). This is acknowledged by Laughlin (1987) who "suggests that most profound changes are likely to originate from inside of organizations. The understanding of the internal processes that stimulate or prevent change requires engaging with organizations" (Correa and Larrinaga, 2015, p. 12).

On the other hand, reflexibility is a "key ingredient in influential engagement research" (Correa and Larrinaga, 2015, p. 17). Researchers that practice intervention research need to make their own agenda visible and reflect on their personal influence on the engaged organization. We have discussed how the choices both in the research design (an experiment) and in the tool's conceptual design led to the tool's rejection. The main author of the paper implemented several techniques used by "insider" researchers (by being consultants or employees of the researched organization) to maintain her ability to reflect on her own practice and development of the tool in order to safeguard her interpretation as a researcher (Correa and Larrinaga, 2015). Despite the difficulties, she maintained the radical significance of her project (Bebbington, 1997, p. 377) so that her accounting would keep sustainability problematic for the organization, and that it would 
provide a "challenge to (current) business practices". From the very beginning of her engagement as a PhD candidate, she challenged the organization's worldview by proposing an experiment "to assist the development of the SD agenda" (Bebbington and Gray, 2001, p.583). According to Gray (2010, p. 14) and Correa and Larrinaga (2015, p. 16), doing sustainability accounting research is a duty of an academic, confronting social and environmental problems, "to make the world a better place and/or contribute in some active way to notions of bettering planetary and/or social well-being". This is what this experiment was about, and despite its non-adoption, we hope to trigger questions, debate, unease and further intervention research to continue the endeavor to pursue accounting for sustainable development.

\section{Conclusion}

We proposed an analysis of the construction of a new sustainability accounting tool based on four strong sustainability principles whose purpose was to further the development of accounting for sustainable development (Bebbington and Larrinaga, 2014). Through our research, we furthered the use of a systemic approach to sustainability within accounting, while defining the capitals as a debt to be repaid. We attempted to define thresholds (through baselines) as a way to accompany the organization towards a less unsustainable way of doing business.

We recognize that any attempt to develop accounting for sustainable development is bound to be partial and more incremental than radical for several reasons. First, there are limits to the transposition of concepts of strong sustainability into accounting. While the philosophy of sustainability principles can be understood, it is barely visible within the accounting itself. Second, social capital is less developed in accounting, notably when it comes to strong sustainability concepts. It is also less developed in practice, leading to difficulty in gathering data. Third, the team at the organization involved decided not to question the economic capital calculations, although this would be recommended to be able to account for sustainable development as a whole. Finally, accounting for thresholds in sustainability is still in the early stages, and it is not clear whether the choices made in experiments will lead the organizations towards sustainability or just reduce unsustainability. However, this research enabled a first test of accounting application of a systemic approach of sustainability and can serve as a basis to further develop this scarcely experimented approach in accounting.

Therefore, we propose that more intervention research projects be conducted in the future (Adams and Larrinaga, 2019). Indeed, there is a need to confront strong sustainability concepts to their practical operationalization. For example, to dive deep into how a system view of sustainability could be better represented and implemented within the tool and its calculations. Moreover, both economic and social capitals need further consideration. The concept of break-even goals developed by Future Fit could also be tested within organizations, including small- and medium-sized companies. Finally, there are ongoing discussions about what could be considered valid maintenance activities for each capital (following the four levels proposed by Bebbington and Gray, 2001, or Upham, 2000), and what "positive" externalities are for organizations, and whether we should account for them from a strong sustainability viewpoint (Kühnen and Hahn, 2019). 
Finally, one might question the use of yet another failed experiment in "accounting for sustainable development". However, this is in line with the goal of engaging with organizations to improve their accountability, "characterized as offering insights into understanding the potential of accounting as a transformative, emancipatory force rather than a word to describe the grudging, partial disclosures designed to maintain the selfinterest of corporations, governments and regulators and their control over others"(Bebbington et al., 2017, p. 29). If human society is to survive the global challenges facing it, then every experiment towards this goal is another node in a network of initiatives designed to change the narrative. 


\section{References}

Adams, C. A., \& Larrinaga-González, C. (2007), "Engaging with organisations in pursuit of improved sustainability accounting and performance", Accounting, Auditing \& Accountability Journal, Vol. 20 No. 3, pp. 333-355.

Adams, C.A. and Larrinaga, C. (2019), "Progress: engaging with organisations in pursuit of improved sustainability accounting and performance", Accounting, Auditing \& Accountability Journal, Vol. 32 No. 8, pp. 2367-2394.

Accounting for Sustainability (2007), Connected reporting, a practical guide with worked examples.

Antheaume, N. (2004), "Valuing external costs. From theory to practice: implications for full cost environmental accounting", European Accounting Review, Vol. 13 No. 3, pp. 443464.

Barbier, E.B. (2019), "The concept of natural capital”, Oxford Review of Economic Policy, Vol. 35 No. 1, pp. 14-36.

Bebbington, J. (1997), "Engagement, education and sustainability a review essay on environmental accounting", Accounting, Auditing \& Accountability Journal, Vol. 10 No. 3, pp. 365-381.

Bebbington, J. (2001), "Sustainable development: a review of the international development, business and accounting literature", Accounting Forum, Vol. 25 No. 2.

Bebbington, J. (2007), Accounting for Sustainable Development Performance, CIMA Publishing, Elsevier.

Bebbington, J. and Gray, R. (1993), "Corporate accountability and the physical environment: social responsibility and accounting beyond profit", Business Strategy and the Environment, Vol. 2 No. 2, pp. 1-11.

Bebbington, J. and Gray, R. (2001), "An account of sustainability: failure, success and a reconceptualization", Critical Perspectives on Accounting, Vol. 12 No. 5, pp. 557-588.

Bebbington, J., Gray, R., Hibbitt, C. and Kirk, E. (2001), "Full cost accounting: An agenda for action". London: Certified Accountants Educational Trust.

Bebbington, J., Brown, J., and Frame, B. (2007), "Accounting technologies and sustainability assessment models", Ecological Economics, Vol. 61 No. 2-3, pp. 224-236.

Bebbington, J. and Larrinaga, C. (2014), "Accounting and sustainable development: An exploration," Accounting, Organizations and Society, Vol. 39 No. 6, pp. 395-413.

Bebbington, J., Russell, S. and Thomson, I. (2017), "Accounting and sustainable development: Reflections and propositions", Critical Perspectives on Accounting, Vol. 48, pp. 21-34. 
Bebbington, J. and Unerman, J. (2018), "Achieving the United Nations Sustainable Development Goals", Accounting, Auditing \& Accountability Journal, Vol. 31 No. 1, pp. 224.

Binswanger, M. (2001), "Technological progress and sustainable development: what about the rebound effect?", Ecological Economics, Vol. 36, No. 1, pp. 119-132.

Birkin, F. (1996). "The ecological accountant: from the cogito to thinking like a mountain”, Critical Perspectives on Accounting, Vol. 7 No. 3, pp. 231-257.

Broman, G. I., \& Robert, K. H. (2017), "A framework for strategic sustainable development", Journal of Cleaner Production, Vol. 140, pp. 17-31.

CICA (1997), "Full Cost Accounting from an Environmental Perspective", Research Report.

Collier, P. M. (2001), "The power of accounting: a field study of local financial management in a police force", Management Accounting Research, Vol. 12 No. 4, pp. 465486.

Correa, C. and Larrinaga, C. (2015), "Engagement research in social and environmental accounting”, Sustainability Accounting, Management and Policy Journal, Vol. 6 No. 1, pp. 528.

Coulson, A. and Adams, C. and Nugent, M. and Haynes, K. (2015), "Exploring metaphors of capitals and the framing of multiple capitals: challenges and opportunities for IR", Sustainability Accounting, Management and Policy Journal, Vol. 6 No. 3, pp. 290-314.

Daily, G.C., Söderqvist, T., Aniyar, S., et al. (2000), 'The Value of Nature and the Nature of Value'", Science, Vol. 289 No. 5478, pp. 395-6.

Etzion, D. and Ferraro, F. (2010), "The role of analogy in the institutionalization of sustainability reporting", Organization Science, Vol. 21 No. 5, pp. 1092-1107.

Feger, C. and Mermet, L. (2017), "A blueprint towards accounting for the management of ecosystems", Accounting, Auditing \& Accountability Journal, Vol. 30 No. 7, pp. 1511-1536.

Folke, C., Hahn, T., Olsson, P. and Norberg, J. (2005), “Adaptive governance of socialecological systems”, Annu. Rev. Environ. Resour., Vol. 30, pp. 441-73.

Folke, C., Carpenter, S.R., Walker,B., Scheffer, M., Chapin, T. and Rockström, J. (2010), "Resilience thinking: integrating resilience, adaptability and transformability", Ecology and Society, Vol. 15 No. 4.

Frame, B. and Cavanagh, J. (2009), "Experiences of sustainability assessment: An awkward adolescence", Accounting Forum, Vol. 33, pp. 195-208.

Fraser, M. (2012), ““Fleshing out” an engagement with a social accounting technology”, 
Future Fit (2019), "Methodology Guide. What the Benchmark is. Its scientific foundations. How it was developed". Available at: https://futurefitbusiness.org/resources/ (accessed August 6 ${ }^{\text {th }}, 2019$ ).

Godard, 0. (2004), "La pensée économique face à la question de l'environnement", Leçons de Philosophie économique, no 2 : Économie normative et philosophie morale, Economica, Paris.

Gray, R. H. (1992), "Accounting and environmentalism: an exploration of the challenge of gently accounting for accountability, transparency and sustainability", Accounting, organization and society, Vol. 17 No. 5, pp. 399-425.

Gray, R., Walters, D., Bebbington, J. and Thompson, I. (1995), “The greening of enterprise: an exploration of the (non) role of environmental accounting and environmental accountants in organizational change", Critical perspectives on accounting, Vol. 6 No. 3, pp. 211-239.

Gray R. (2010), "Is accounting for sustainability actually accounting for sustainability...and how would we know? An exploration of narratives of organisations and the planet", Accounting, Organizations and Society, Vol. 35 No. 1, pp. 47-62.

Gray, R. H. and Milne, M. J. (2004), "Towards reporting on the triple bottom line: Mirages, methods and myths", in A. Henriques \& J. Richardson (Eds.), The triple bottom line: Does it all add up? London: Earthscan.

Hastrup, K. (1997), "The dynamics of anthropological theory", Cultural Dynamics, Vol. 9 No. 3, pp. 351-371.

Hendriksen, B., Weimer, J., and McKenzie, M. (2016), “Approaches to quantify value from business to society: Case studies of KPMG's true value methodology", Sustainability Accounting, Management and Policy Journal, Vol. 7 No. 4, pp. 474-493.

Herbohn, K. (2005), "A full cost environmental accounting experiment", Accounting, Organizations and Society, Vol. 30 No. 6, pp. 519-536.

Holmberg, J., and Robert, K. H. (2000), "Backcasting-A framework for strategic planning", International Journal of Sustainable Development \& World Ecology, Vol. 7 No. 4, pp. 291-308.

Hoekstra, A. Y., Bredenhoff-Bijlsma, R., and Krol, M. S. (2018), "The control versus resilience rationale for managing systems under uncertainty", Environmental research letters, Vol. 13 No. 10.

Howes, R. (2000). “Corporate environmental accounting: accounting for environmentally sustainable profits", in John Proops \& Sandrine Simon (Eds.), Greening the accounts, a volume in the international library of ecological economics. London: Edward Elgar Publishers. 
Huizing, A. and Dekker, H. C. (1992), "Helping to pull our planet out of the red: an environmental report of BSO/Origin", Accounting, organization and society, Vol. 17 No. 5, pp. 449-458.

IIRC (2013), "The International IR Framework", available at: http://integratedreporting.org/resource/international-ir-framework/ (accessed August $\left.6^{\text {th }}, 2019\right)$.

ISO (2006), "ISO 14040, 2006. Environmental management - life cycle assessment principles and framework".

Jonsson, S. and Lukka, K. (2007), "There and back again: doing interventionist research in management accounting", In C. S. Chapman, A. G. Hopwood, \& M. D. Shields (Eds.), Handbook of management accounting research. Amsterdam: Elsevier.

KPMG (2014), "A new vision of value: connecting corporate and societal value creation", Report, KPMG International Cooperative, available at: https://assets.kpmg/content/dam/kpmg/pdf/2014/10/a-new-vision-of-value-v1.pdf (Accessed, August 6 ${ }^{\text {th }}$ 2019).

Kühnen, M. and Hahn, R. (2019), "From SLCA to Positive Sustainability Performance Measurement: A Two-Tier Delphi Study", Journal of Industrial Ecology, Vol. 23, pp. 615634.

Lamberton, G. (2000), "Accounting for sustainable development-A case study of city farm", Critical Perspectives on Accounting, Vol. 11 No. 5, pp. 583-605.

Laughlin, R.C. (1987), "Accounting systems in organisational contexts: a case for critical theory", Accounting, Organizations and Society, Vol. 12 No. 5, pp. 479-502.

Martineau, R. and Lafontaine, J. (2019), "When carbon accounting systems make us forget nature: from commodification to reification", Sustainability Accounting, Management and Policy Journal, Vol. ahead-of-print No. ahead-of-print.

Milne, M.J. (1996), "On sustainability, the environment and management accounting", Management Accounting Research, Vol. 7 No. 1, pp. 135-161.

Missimer, M., Robert, K. H., and Broman, G. (2017), "A strategic approach to social sustainability-Part 2: exploring the social system", Journal ofCleaner Production, Vol. 140, pp. 32-41.

Natural Step Canada, The Sustainability Primer (2010), available at http://www.naturalstep.ca/sites/default/files/sustainability-primer.pdf (accessed 08 September 2017) 
Noël, J. F. and O'Connor, M. (1998), "Strong sustainability and critical natural capital” in Valuation for Sustainable Development: Methods and Policy Indicators. Edward Elgar, Cheltenham, pp. 75-97.

Passet, R. (1979), L'économique et le vivant, Payot, re-edited 1996 Economica, Paris.

Plane, J-M. (2000), Méthodes de recherche intervention en management, L'Harmattan.

Rambaud, A. and Richard, J. (2015), "The "Triple Depreciation Line" instead of the "Triple Bottom Line": towards a genuine integrated reporting", Critical Perspectives on Accounting, Vol. 33, pp. 92-116.

Raworth, K. (2017), Doughnut Economics: Seven Ways to Think Like a 21st-Century Economist, Random House Business.

Rockström, J., W. Steffen, K. Noone, et al. (2009), "Planetary boundaries: exploring the safe operating space for humanity”, Ecology and Society, Vol. 14 No. 2.

Russell, S., Milne, M. J., \& Dey, C. (2017), "Accounts of nature and the nature of accounts: critical reflections on environmental accounting and propositions for ecologically informed accounting", Accounting, Auditing \& Accountability Journal, Vol. 30(7), 14261458.

Sala, S., Ciuffo, B., \& Nijkamp, P. (2015), “A systemic framework for sustainability assessment", Ecological Economics, Vol. 119, 314-325.

Soin, K., Seal, W., and Cullen, J. (2002), “ABC and organizational change: an institutional perspective”, Management Accounting Research, Vol. 13 No. 2, pp. 249-271.

Steffen, W., Richardson, K., Rockström, J., Cornell, S. E., Fetzer, I., Bennett, E. M., ... and Folke, C. (2015), "Planetary boundaries: Guiding human development on a changing planet”, Science, Vol. 347 No. 6223.

Unerman, J., Bebbington, J. and O'Dwyer, B. (2018), “Corporate reporting and accounting for externalities”, Accounting and Business Research, Vol. 48 No. 5, pp. 497-522.

Upham, P. (2000), "An assessment of The Natural Step theory of sustainability”, Journal of Cleaner Production, Vol. 8, pp. 445-454.

WCED (1987), Report of the World Commission on Environment and Development: Our Common Future, Oxford University Press: Oxford, UK. 
Table 1: Meetings organized during the project

\begin{tabular}{|l|c|c|}
\hline \multicolumn{2}{|c|}{ Board of Directors' involvement } \\
\hline \multicolumn{1}{|c|}{ Nature } & Date & Duration (Minutes) \\
\hline Research presentation and request for volunteers & $22 / 03 / 2016$ & 40 \\
\hline Work on preliminary documents & $03 / 07 / 2016$ & $\begin{array}{c}60 \text { (theoretical time needed } \\
\text { per participant) }\end{array}$ \\
\hline $1^{\text {st }}$ working meeting & $11 / 07 / 2016$ & 150 \\
\hline $2^{\text {nd }}$ working meeting & $21 / 07 / 2016$ & 120 \\
\hline
\end{tabular}

\begin{tabular}{|l|r|}
\hline \multicolumn{2}{|c|}{ Sponsors' meetings } \\
\hline \multicolumn{1}{|c|}{ Date } & $\begin{array}{c}\text { Duration } \\
\text { (Minutes) }\end{array}$ \\
\hline December 2016 & 100 \\
\hline March 2017 & 90 \\
\hline April 2017 & 60 \\
\hline June 2017 & 90 \\
\hline September 2017 & 90 \\
\hline December 2017 & 75 \\
\hline June 2018 & 55 \\
\hline
\end{tabular}


Table 2: The eight Sustainability Principles (SP) derived from Broman and Robert (2017)

\begin{tabular}{|c|c|c|c|}
\hline CODE & CAPITAL & $\begin{array}{c}\text { SUSTAINABILITY } \\
\text { PRINCIPLE }\end{array}$ & DETAILS \\
\hline ESP1 & NATURAL & $\begin{array}{l}\text { In a sustainable society, } \\
\text { nature is not subject to } \\
\text { systematically increasing } \\
\text { concentrations of } \\
\text { substances extracted } \\
\text { from the Earth's crust. }\end{array}$ & $\begin{array}{l}\text { This means limiting extraction and } \\
\text { ensuring that concentrations of } \\
\text { lithospheric substances do not } \\
\text { systematically increase in the atmosphere, } \\
\text { oceans, soil or other parts of nature (e.g. } \\
\text { fossil carbon and metals). }\end{array}$ \\
\hline ESP2 & NATURAL & $\begin{array}{l}\text { In a sustainable society, } \\
\text { nature is not subject to } \\
\text { systematically increasing } \\
\text { concentrations of } \\
\text { substances produced by } \\
\text { society. }\end{array}$ & $\begin{array}{l}\text { This means conscious molecular design, } \\
\text { limited production and ensuring that } \\
\text { concentrations of societally produced } \\
\text { molecules and nuclides do not } \\
\text { systematically increase in the atmosphere, } \\
\text { oceans, soil or other parts of nature (e.g. } \\
\text { NOx and CFCs). }\end{array}$ \\
\hline ESP3 & NATURAL & $\begin{array}{l}\text { In a sustainable society, } \\
\text { nature is not subject to } \\
\text { systematically increasing } \\
\text { degradation by physical } \\
\text { means. }\end{array}$ & $\begin{array}{l}\text { This means that the area, thickness and } \\
\text { quality of soils, the availability of fresh } \\
\text { water, biodiversity and other aspects of } \\
\text { biological productivity and resilience are } \\
\text { not systematically deteriorated by } \\
\text { mismanagement, displacement or other } \\
\text { forms of physical manipulation (e.g. over- } \\
\text { exploitation of forests and over-fishing). }\end{array}$ \\
\hline SSP1 & SOCIETAL & $\begin{array}{l}\text { In a sustainable society, } \\
\text { people are not subject to } \\
\text { structural obstacles to } \\
\text { health. }\end{array}$ & $\begin{array}{l}\text { This means that people are not exposed to } \\
\text { social conditions that systematically } \\
\text { undermine the possibility of avoiding } \\
\text { injury and illness, whether physical, } \\
\text { mental or emotional (e.g. dangerous } \\
\text { working conditions or insufficient rest } \\
\text { from work). }\end{array}$ \\
\hline SSP2 & SOCIETAL & $\begin{array}{l}\text { In a sustainable society, } \\
\text { people are not subject to } \\
\text { structural obstacles to } \\
\text { competence. }\end{array}$ & $\begin{array}{l}\text { This means that people are not } \\
\text { systematically hindered from learning and } \\
\text { developing competence individually } \\
\text { and/or together (e.g. by obstacles to } \\
\text { education or insufficient opportunities for } \\
\text { personal development). }\end{array}$ \\
\hline SSP3 & SOCIETAL & $\begin{array}{l}\text { In a sustainable society, } \\
\text { people are not subject to } \\
\text { structural obstacles to } \\
\text { influence. }\end{array}$ & $\begin{array}{l}\text { This means that people are not } \\
\text { systematically hindered from helping to } \\
\text { shape the social systems they are part of } \\
\text { (e.g. by restraining free speech or } \\
\text { neglecting opinions). }\end{array}$ \\
\hline SSP4 & SOCIETAL & $\begin{array}{l}\text { In a sustainable society, } \\
\text { people are not subject to } \\
\text { structural obstacles to } \\
\text { impartiality. }\end{array}$ & $\begin{array}{l}\text { This means that people are not } \\
\text { systematically exposed to partial } \\
\text { treatment e.g. by discrimination or unfair } \\
\text { selection for job positions). }\end{array}$ \\
\hline SSP5 & SOCIETAL & $\begin{array}{l}\text { In a sustainable society, } \\
\text { people are not subject to } \\
\text { structural obstacles to } \\
\text { meaning-making. }\end{array}$ & $\begin{array}{l}\text { This means that people are not } \\
\text { systematically hindered from creating } \\
\text { individual meaning and co-creating } \\
\text { common meaning (e.g. by inhibiting } \\
\text { cultural expression or obstacles to co- } \\
\text { creation of purposeful conditions). }\end{array}$ \\
\hline
\end{tabular}


Table 4: How our sustainability accounting tool intersects with other models

\begin{tabular}{|l|l|}
\hline $\begin{array}{l}\text { Principles of the sustainability } \\
\text { accounting tool }\end{array}$ & $\begin{array}{l}\text { Tools that use the same concepts and authors } \\
\text { that cite these concepts }\end{array}$ \\
\hline $\begin{array}{l}\text { Capital as debt, maintenance } \\
\text { principal }\end{array}$ & $\begin{array}{l}\text { Capital as debt: TDL-CARE (Richard and } \\
\text { Rambaud, 2015), maintenance principal } \\
\text { (Bebbington and Gray, 2001; Huizing and Dekker, } \\
\text { 1992; Howes, 2000) } \\
\text { Authors that mention maintenance and capital as } \\
\text { debt: Gray, 1992; Birkin, 1996 }\end{array}$ \\
\hline $\begin{array}{l}\text { Systemic nature of sustainability } \\
\text { and resilience }\end{array}$ & $\begin{array}{l}\text { Future Fit (2019), secondary effects are taken into } \\
\text { consideration by Life Cycle Assessments } \\
\text { Authors that refer to the systemic nature of } \\
\text { sustainability: Bebbington } \text { et al., 2019; } \\
\text { Bebbington and Unerman, 2018; Gray and Milne, } \\
\text { 2004; Birkin, 1996 }\end{array}$ \\
\hline $\begin{array}{l}\text { Scope (beyond the organization's } \\
\text { boundaries) }\end{array}$ & $\begin{array}{l}\text { Life Cycle Assessments, Full Cost Accounting (e.g. } \\
\text { the E P\&L) } \\
\text { Authors that mention a broadening scope: } \\
\text { Bebbington and Larrinaga, 2014; Russell et al., } \\
\text { 2017; Bebbington and Unerman, 2018, Milne and } \\
\text { Gray, 2013; Dey and Russell, 2014 }\end{array}$ \\
\hline Thresholds of sustainability & $\begin{array}{l}\text { Sustainability Cost (Bebbington and Gray, 2001), } \\
\text { the City Farm (Lamberton, 2000) } \\
\text { Authors that mention thresholds and carrying } \\
\text { capacity: Milne, 1996; Atkinson, 2000 }\end{array}$ \\
\hline
\end{tabular}


Table 4: Theoretical example, baseline calculation

\begin{tabular}{|l|r|r|r|}
\hline \multicolumn{3}{|c|}{ Year zero : Baseline calculation } \\
\hline \multicolumn{3}{|c|}{ Natural capital (proxi A) } \\
\hline Initial unremediated fixed assets impact & 1000 & baseline & 11500 \\
\hline Initial unremediated Operational Impact & 10500 & & 11500 \\
\hline TOTAL BALANCE & 11500 & & \\
\hline & & & \\
\hline Products loss & 10000 & & \\
\hline Activity loss & 500 & & \\
\hline TOTAL OPERATIONAL IMPACT & 10500 & & \\
\hline
\end{tabular}


Table 5: Theoretical example, business as usual, 10\% growth, year 1

\begin{tabular}{|c|c|c|c|}
\hline \multicolumn{4}{|c|}{ Year 1 (business as usual, $10 \%$ growth, including in fixed assets impact) } \\
\hline \multicolumn{4}{|c|}{ Natural capital (proxi A) } \\
\hline \multicolumn{2}{|l|}{ ASSET } & \multicolumn{2}{|c|}{ LIABILITY } \\
\hline Initial unremediated fixed assets impact & 1000 & baseline & 11500 \\
\hline & & result & -1150 \\
\hline Initial unremediated Operational Impact & 10500 & debt & 1150 \\
\hline TOTAL BALANCE & 11500 & & 11500 \\
\hline Products impact variation (loss) & 1000 & & \\
\hline $\begin{array}{l}\text { Activity and fixed assets impact variation } \\
\text { (loss) }\end{array}$ & 150 & & \\
\hline
\end{tabular}


Table 6: Seven proxies for the natural capital

\begin{tabular}{|c|c|c|c|c|c|c|c|c|}
\hline & SP & ESP1 & \multicolumn{4}{|c|}{ ESP2 } & \multicolumn{2}{|c|}{ ESP3 } \\
\hline & \multirow[b]{2}{*}{ PROXI } & \multirow[b]{2}{*}{$\begin{array}{c}\text { Mineral, Fossil \& } \\
\text { Non Renewable } \\
\text { Resource } \\
\text { Depletion }\end{array}$} & \multirow[b]{2}{*}{$\begin{array}{c}\text { Global Warming } \\
\text { Potential }\end{array}$} & \multirow[b]{2}{*}{ Air Acidification } & \multirow[b]{2}{*}{$\begin{array}{l}\text { Freshwater } \\
\text { Eutrophication }\end{array}$} & \multirow[b]{2}{*}{$\begin{array}{c}\text { Marine } \\
\text { Eutrophication }\end{array}$} & Land use & \multirow[b]{2}{*}{ Water footprint } \\
\hline & & & & & & & $\begin{array}{c}\text { Land use } \\
\text { (Transformation } \\
\text { from natural to } \\
\text { agricultural) for } \\
\text { products }\end{array}$ & \\
\hline & UNIT & kg Sb eq. & kg CO2 eq. & kg SO2 eq. & kg N eq. & kg $P$ eq. & m2 & m3 \\
\hline \multirow{2}{*}{ BALANCE SHEET } & Assets & \multicolumn{7}{|c|}{ Asset Acquisition LCA } \\
\hline & Liabilities & \multicolumn{7}{|c|}{ YEAR 0 total impact. Science-based targets will be considered when available } \\
\hline \multirow{2}{*}{$\begin{array}{l}\text { TRANSACTION } \\
\text { OBJECTS P\&L }\end{array}$} & Loss & \multicolumn{7}{|c|}{ Transaction matters LCA } \\
\hline & Profit & \multicolumn{7}{|c|}{ Effects of supplier compensation (on the year it becomes effective) } \\
\hline \multirow[b]{2}{*}{ ACTIVITY P\&L } & Loss & \multicolumn{7}{|c|}{ Activity LCA data } \\
\hline & Profit & \multicolumn{7}{|c|}{$\begin{array}{c}\text { Compensation will be accounted for on the year the action has a real effect (substance concentration reduction or restoration of } \\
\text { natural environments) }\end{array}$} \\
\hline
\end{tabular}


Table 7: Seven proxies for the social capital

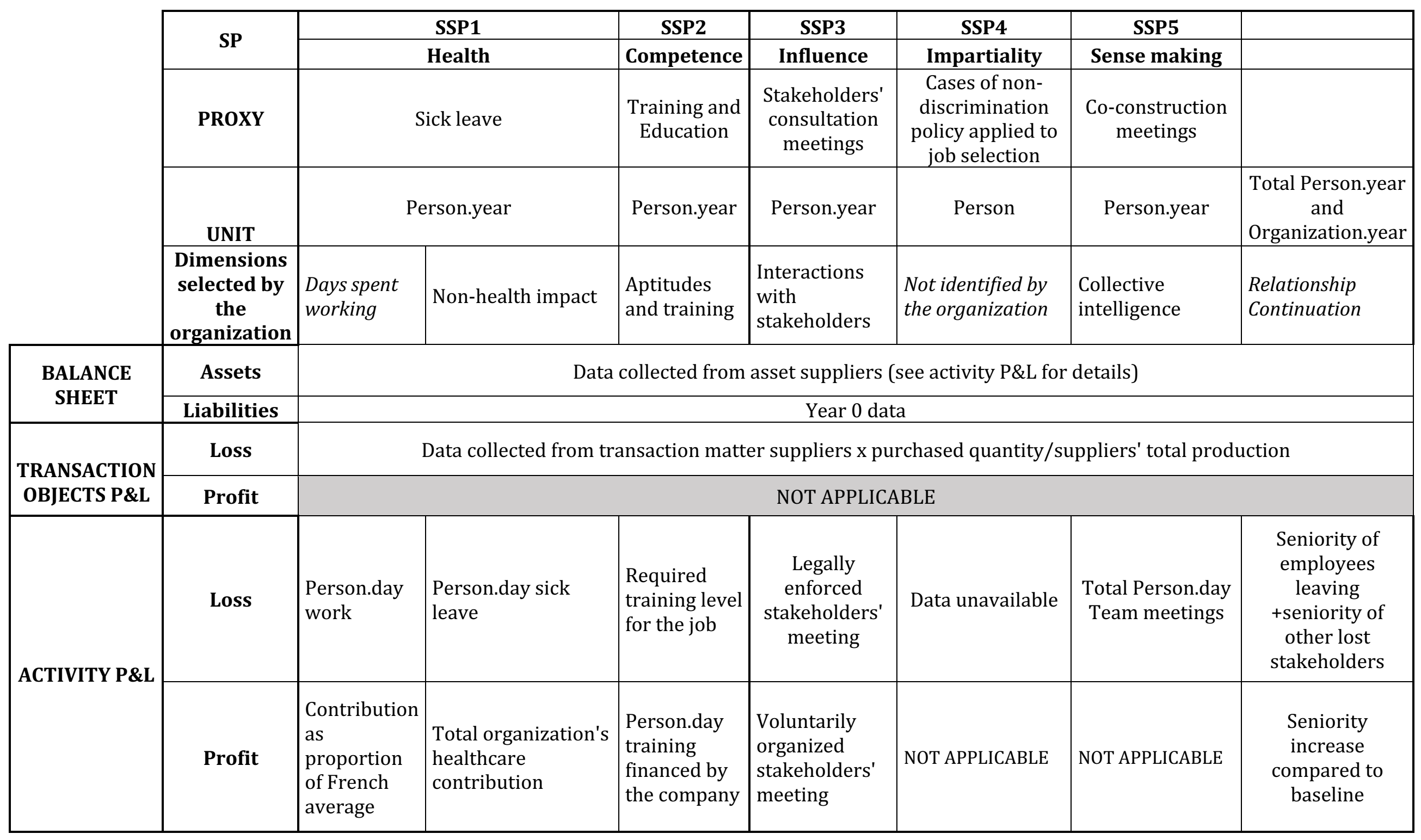




\begin{tabular}{|c|c|c|c|c|c|c|c|c|c|c|c|c|c|c|c|}
\hline \multicolumn{16}{|c|}{ Year 1 (business as usual, $5 \%$ growth, no change in assets) } \\
\hline \multicolumn{8}{|c|}{ ASSET } & \multicolumn{8}{|c|}{ LIABILITY } \\
\hline & ESP1 & \multicolumn{4}{|c|}{ ESP2 } & \multicolumn{2}{|c|}{ ESP3 } & & ESP1 & \multicolumn{4}{|c|}{ ESP2 } & \multicolumn{2}{|c|}{ ESP3 } \\
\hline & \multirow[b]{2}{*}{$\begin{array}{c}\text { Non-renewable } \\
\text { CED }\end{array}$} & \multirow[b]{2}{*}{ Climate change } & \multirow[b]{2}{*}{$\begin{array}{c}\text { Terrestrial } \\
\text { acidification }\end{array}$} & \multirow[b]{2}{*}{$\begin{array}{c}\text { Freshwater } \\
\text { eutrophication }\end{array}$} & \multirow[b]{2}{*}{$\begin{array}{c}\text { Marine } \\
\text { eutrophication }\end{array}$} & \multirow[b]{2}{*}{$\begin{array}{l}\text { Water use } \\
\text { AWARE }\end{array}$} & \multirow{2}{*}{\begin{tabular}{|c|} 
Land Use \\
$\begin{array}{c}\text { Natural land } \\
\text { transformation }\end{array}$
\end{tabular}} & & \multirow[b]{2}{*}{$\begin{array}{c}\text { Non-renewable } \\
\text { CED }\end{array}$} & \multirow[b]{2}{*}{ Climate change } & \multirow[b]{2}{*}{\begin{tabular}{|c|} 
Terrestrial \\
acidification
\end{tabular}} & \multirow[b]{2}{*}{$\begin{array}{c}\text { Freshwater } \\
\text { eutrophicati } \\
\text { on }\end{array}$} & \multirow[b]{2}{*}{$\begin{array}{c}\text { Marine } \\
\text { eutrophicatio } \\
\mathrm{n}\end{array}$} & \multirow[b]{2}{*}{$\begin{array}{l}\text { Water use } \\
\text { AWARE }\end{array}$} & \multirow{2}{*}{\begin{tabular}{|l|} 
Land Use \\
\\
Natural land \\
transformation
\end{tabular}} \\
\hline & & & & & & & & & & & & & & & \\
\hline & $\mathrm{kg} \mathrm{Sb}$ eq. & $\mathrm{kg} \mathrm{CO} 2$ eq. & $\mathrm{kg} \mathrm{SO2} \mathrm{eq.}$ & kg N eq. & $\mathrm{kg} P$ eq. & $\mathrm{m} 3$ & $\mathrm{~m} 2$ & & $\mathrm{~kg}$ Sb eq. & kg CO2 eq. & $\mathrm{kg} \mathrm{S02}$ eq. & $\mathrm{kg} \mathrm{N}$ eq. & $\mathrm{kg} P$ eq. & $\mathrm{m} 3$ & $\mathrm{~m} 2$ \\
\hline $\begin{array}{l}\text { Initial unremediated impact of } \\
\text { fixed assets }\end{array}$ & 65820 & 49412679 & 342020 & 37803 & 17771 \ & 12099524 & $7815 \mathrm{E}$ & RASEINEF & 4764179322 & 520074279 & 4683861 & 261036 & 2654.192 & 6535500140 & 677657 \\
\hline Initial unremediated impact of & 05020 & 4541207 & 342020 & 37803 & $17 / 71$ & 12099524 & 1815 & BASELINE & $4 / 64179324$ & $5200 / 4279$ & 4683861 & 261036 & 2654192 & 6535500140 & $6 / 765 /$ \\
\hline \multirow{2}{*}{$\begin{array}{l}\text { Inttial unremediated impact of } \\
\text { operations }\end{array}$} & 4764113502 & 470661599 & 4341840 & 223233 & 2636421 & 6523400616 & $669842 \mathrm{~F}$ & RESULT & -238205642 & -23292658 & -216643 & -11133 & -131800 & -326141895 & -33445 \\
\hline & & & & & & & & DEBT & 238205642 & 23292658 & 216643 & 11133 & 131800 & 326141895 & 33445 \\
\hline TOTAL BALANCE & 4764179322 & 520074279 & 4683861 & 261036 & 2654192 & 6535500140 & 677657 & & 4764179322 & 520074279 & 4683861 & 261036 & 2654192 & 6535500140 & 677657 \\
\hline Variation in product impact (loss) & 238205640 & 23236036 & 216421 & 11116 & 131781 & 325096616 & 33437 & & & & & & & & \\
\hline Variation in impact of activity and & & & & & & & & & & & & & & & \\
\hline $\begin{array}{l}\text { fixed assets } \\
\text { TOTALLOSS }\end{array}$ & \begin{tabular}{r|}
3 \\
238205642
\end{tabular} & \begin{tabular}{r|}
56622 \\
23292658
\end{tabular} & \begin{tabular}{r|}
223 \\
216643
\end{tabular} & $\begin{array}{r}16 \\
11133\end{array}$ & $\begin{array}{r}19 \\
131800\end{array}$ & \begin{tabular}{r|}
1045279 \\
326141895
\end{tabular} & $\begin{array}{r}8 \\
33445\end{array}$ & & & & & & & & \\
\hline
\end{tabular}

\begin{tabular}{|c|c|c|c|c|c|c|c|c|c|c|c|c|c|c|c|}
\hline \multicolumn{16}{|c|}{ Year 2 (business as usual, $5 \%$ growth, no change in assets) } \\
\hline \multicolumn{8}{|c|}{ ASSET } & \multicolumn{8}{|c|}{ LIABILITY } \\
\hline & ESP1 & \multicolumn{4}{|c|}{ ESP2 } & \multicolumn{2}{|c|}{ ESP3 } & & ESP1 & \multicolumn{4}{|c|}{ ESP2 } & \multicolumn{2}{|c|}{ ESP3 } \\
\hline & & & & & & & Land Use & & & & & & & & Land Use \\
\hline & $\begin{array}{l}\text { Non-renewable } \\
\text { CED }\end{array}$ & Climate change & $\begin{array}{c}\text { Terrestrial } \\
\text { acidification }\end{array}$ & $\begin{array}{c}\text { Freshwater } \\
\text { eutrophication }\end{array}$ & $\begin{array}{c}\text { Marine } \\
\text { eutrophication }\end{array}$ & $\begin{array}{l}\text { Water use } \\
\text { AWARE }\end{array}$ & $\begin{array}{c}\text { Natural land } \\
\text { transformation }\end{array}$ & & $\begin{array}{c}\text { Non-renewable } \\
\text { CED }\end{array}$ & Climate change & $\begin{array}{c}\text { Terrestrial } \\
\text { acidification }\end{array}$ & \begin{tabular}{|c|} 
Freshwater \\
eutrophicati \\
on
\end{tabular} & $\begin{array}{c}\text { Marine } \\
\text { eutrophicatio } \\
\mathrm{n}\end{array}$ & $\begin{array}{l}\text { Water use } \\
\text { AWARE }\end{array}$ & $\begin{array}{c}\text { Natural land } \\
\text { transformation }\end{array}$ \\
\hline & $\mathrm{kg}$ Sb eq. & $\mathrm{kg} \mathrm{CO} 2$ eq. & $\mathrm{kg} \mathrm{SO} 2$ eq. & $\mathrm{kg} \mathrm{N}$ eq. & $\mathrm{kg} P$ eq. & $\mathrm{m} 3$ & $\mathrm{~m} 2$ & & $\mathrm{~kg}$ Sb eq. & $\mathrm{kg} \mathrm{CO2} \mathrm{eq.}$ & $\mathrm{kg} \mathrm{SO2}$ eq. & kg N eq. & $\mathrm{kg} P$ eq. & $\mathrm{m} 3$ & $\mathrm{~m} 2$ \\
\hline $\begin{array}{l}\text { Initial unremediated impact of } \\
\text { fixed assets }\end{array}$ & 65820 & 49412679 & 342020 & 37803 & 17771 & 12099524 & 7815 & BASELINE & 4764179322 & 520074279 & 4683861 & 261036 & 2654192 & 6535500140 & 677657 \\
\hline $\begin{array}{l}\text { Initial unremediated impact of } \\
\text { operations }\end{array}$ & 4764113502 & 470661599 & 4341840 & 223233 & 2636421 & 6523400616 & 669842 & BESULT & -250115924 & -24457291 & -227476 & -11689 & -138390 & -342448989 & -35117 \\
\hline & & & & & & & & amount carried & & & & & & & \\
\hline 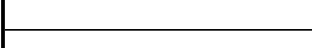 & & & & & & & & forward & $\begin{array}{r}-238205642 \\
488321567\end{array}$ & $\frac{-23292658}{47749949}$ & \begin{tabular}{r|}
-216643 \\
444119
\end{tabular} & -11133 & -131800 & -326141895 & $\begin{array}{r}-33445 \\
68562\end{array}$ \\
\hline TOTAL BALANCE & 4764179322 & 520074279 & 4683861 & 261036 & 2654192 & 6535500140 & 677657 & DEBT & $\frac{488321561}{4764179322}$ & 520074279 & $\begin{array}{r}444119 \\
4683861\end{array}$ & $\begin{array}{r}22822 \\
261036\end{array}$ & $\begin{array}{r}270191 \\
2654192\end{array}$ & \begin{tabular}{r|}
668590884 \\
6535500140
\end{tabular} & $\begin{aligned} 68562 \\
677657\end{aligned}$ \\
\hline Variation in product impact (loss) & 250115922 & 24397838 & 227242 & 11672 & 138370 & 341351447 & 35109 & & & & & & & & \\
\hline Variation in impact of activity and & & & & & & & & & & & & & & & \\
\hline fixed assets (loss) & 3 & 59453 & 234 & 17 & 20 & 1097543 & & & & & & & & & \\
\hline TOTALLOSS & 250115924 & 24457291 & 227476 & 11689 & 138390 & 342448989 & 35117 & & & & & & & & \\
\hline
\end{tabular}




\section{Figures}

Figure 1: Passet (1979)

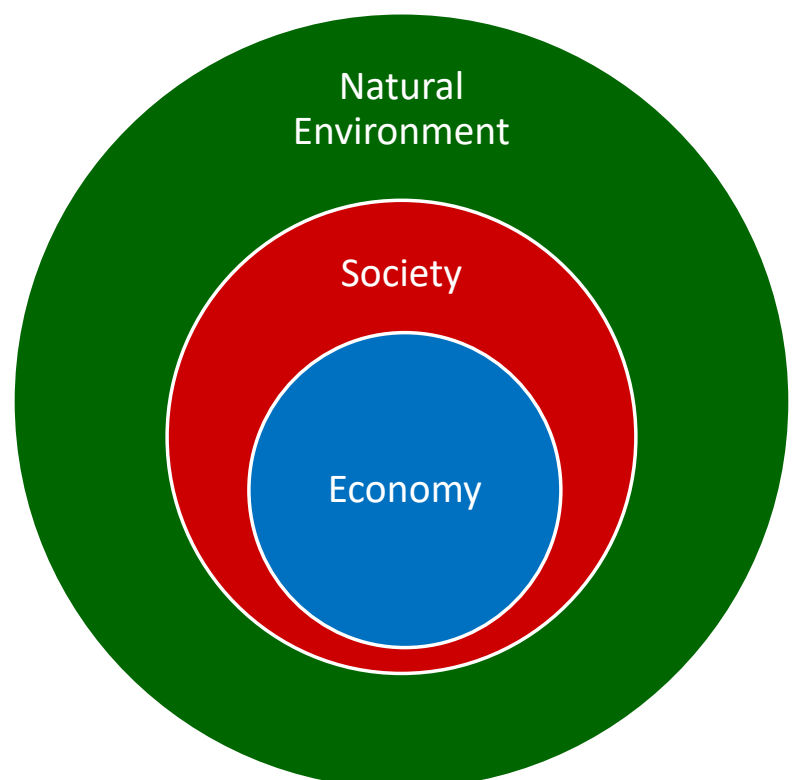

Figure 2: Systemic nature of sustainability and resilience

LCA-based proxies are used to inform on compliance with sustainability principles, which in turn implies maintenance of the system's resilience

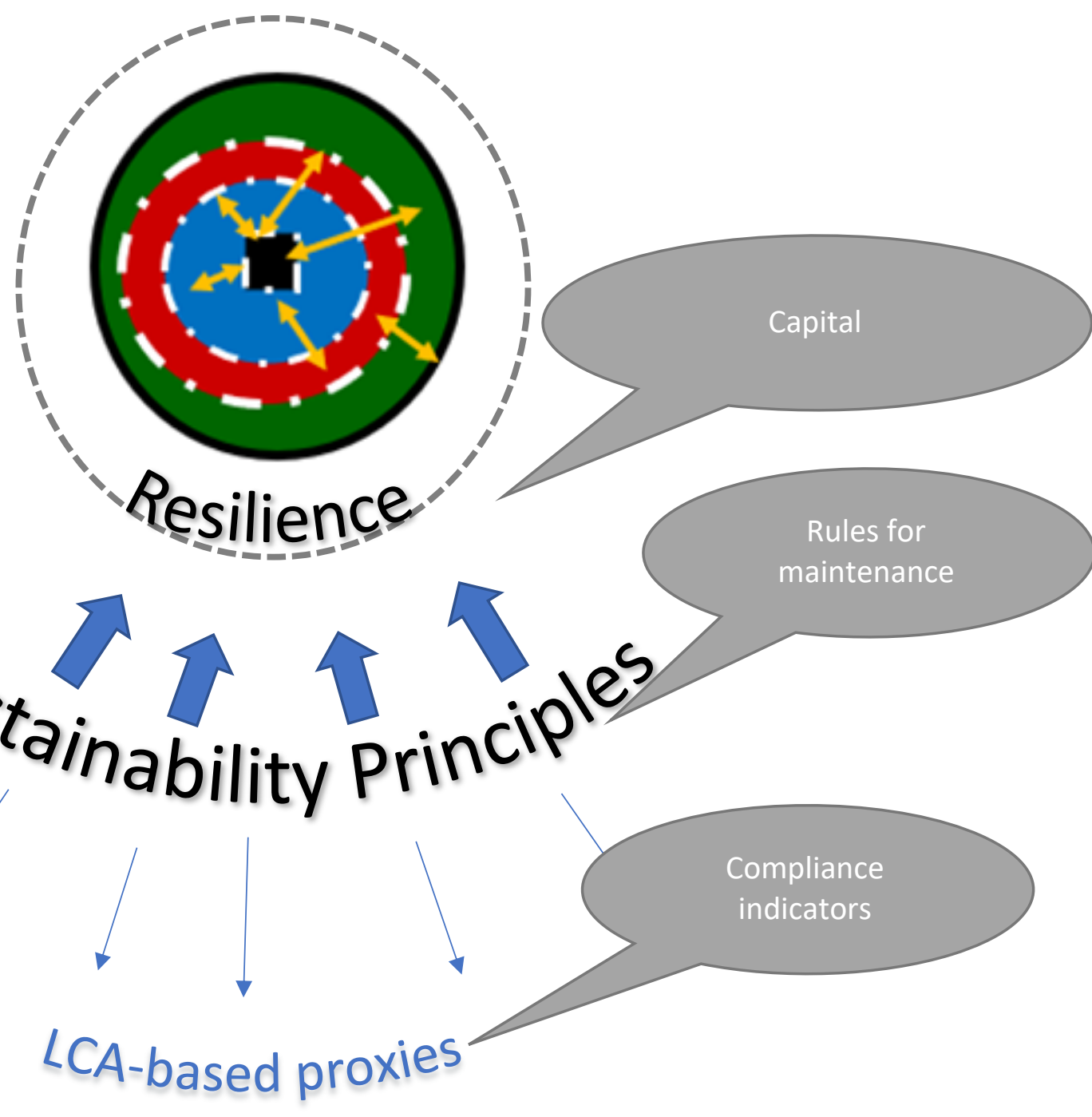


